\title{
Mitigating Bycatch: Novel Insights to Multidisciplinary Approaches
}

\author{
Dale Squires ${ }^{1 *}$, Lisa T. Ballance ${ }^{2}$, Laurent Dagorn ${ }^{1}$, Peter H. Dutton ${ }^{3}$ and Rebecca Lent ${ }^{4}$ \\ ${ }^{1}$ Southwest Fisheries Science Center, NOAA Fisheries, La Jolla, CA, United States, ${ }^{2}$ Marine Mammal Institute, Oregon State \\ University, Corvallis, OR, United States, ${ }^{3}$ UMR 248 MARBEC Institut de Recherche pour le Développement (IRD), Sète, \\ France, ${ }^{4}$ Executive Secretary, International Whaling Commission, Cambridge, United Kingdom
}

OPEN ACCESS

Edited by:

Rob Harcourt,

Macquarie University, Australia

Reviewed by:

Rebecca L. Lewison,

San Diego State University,

United States

Sean Pascoe,

Commonwealth Scientific and Industrial Research Organisation

(CSIRO), Australia

*Correspondence:

Dale Squires

Dale.Squires@noaa.gov

Specialty section:

This article was submitted to Marine Affairs and Policy,

a section of the journal

Frontiers in Marine Science

Received: 01 October 2020 Accepted: 04 January 2021

Published: 19 March 2021

Citation:

Squires D, Balance LT, Dagorn L,

Dutton PH and Lent R (2021)

Mitigating Bycatch: Novel Insights

to Multidisciplinary Approaches.

Front. Mar. Sci. 8:613285.

doi: 10.3389/fmars.2021.613285
Fisheries bycatch conservation and management can be analyzed and implemented through the biodiversity mitigation hierarchy using one of four basic approaches: (1) private solutions, including voluntary, moral suasion, and intrinsic motivation; (2) direct or "command-and-control" regulation starting from the fishery management authority down to the vessel; (3) incentive- or market-based to alter producer and consumer behavior and decision-making; and (4) hybrid of direct and incentive-based regulation through liability laws. Lessons can be learned from terrestrial and energy conservation, water management, forestry, and atmospheric pollution measures, such as the use of offsets, tradeable rights to externalities, and liability considerations. General bycatch conservation and management principles emerge based on a multidisciplinary approach and a wide array of private and public measures for incentivizing bycatch mitigation.

Keywords: bycatch, biodiversity mitigation hierarchy, inter-disciplinary, conservation, regulation

\section{CONTEXT: THE BYCATCH ISSUE}

Bycatch refers most often to those species incidentally taken in fishing operations aimed at other (target) species. Bycatch in this paper refers to species accidentally caught other than the target species, brought on board, dead or alive, and that can therefore be either released alive, discarded dead, or landed. Bycatch can be other finfish (including undersized target species), protected species (fishes, sea turtles, marine mammals, and seabirds), live corals, or sponge reefs. We include habitat impact (Holland and Schnier, 2006; Driscoll et al., 2017) with bycatch (hereafter simply bycatch). Central to this paper is the fact that bycatch species and living habitats include vulnerable, threatened, endangered, protected or otherwise emblematic species for which the take should be minimized. Bycatch in this paper is extended to include habitat impact.

Economists classify bycatch into two types. The first type is non-target species that are commercially harvested and receive a market price, but harvest is not at the ecologicallyeconomically optimum level due to size, age, or contribution to ecosystems. The market price does not capture the full costs of foregone biodiversity and ecosystem services, including impacts on population growth and food webs, because the bycatch is underpriced. Examples could include a commercially landed fish species caught before reaching sexual maturity or a plankton foraging fish contributing to the food web. The second type of bycatch is threatened, endangered or protected species that are prohibited for retention. Examples include seabirds and sea turtles ensnared in pelagic longline gear and marine mammals caught in drift gillnets. Because these species do not have a formal market, the bycatch is 'unpriced,' even though the species do have non-market value through their contribution to biodiversity, the ecosystem, and existence.

This paper, part of a special issue on bycatch and its mitigation, develops a broad-based conservation framework and suite of policy instruments to address bycatch, drawn from marine 
and terrestrial biodiversity conservation, pollution, and climate mitigation examples. While the ecosystem approach to fisheries has largely focused on harvest strategies, the future of fisheries management will also benefit from the conservation and regulatory framework described in this paper. Most, if not all, conclusions on bycatch mitigation that have been based on harvest strategies can be broadly applied to environmental protection of living habitats and to marine biodiversity conservation in general, and therefore, to complete implementation of the ecosystem approach to fisheries. The focus of this paper and the associated case studies pertains to commercial fisheries, but when possible, artisanal fisheries are also considered.

The paper develops this broad-based conservation framework through three specific objectives. First, using the conservation biology mitigation hierarchy as a broad framework, the paper provides new insights into the suitability of the no net loss objective. Second, the paper extends the previous bycatch management literature by developing four regulatory categories for fisheries bycatch mitigation: private, direct regulation (top-down and command-and-control), incentive (market-based), and hybrid. The previous literature, reviewed below, largely focused upon reviewing different incentivebased approaches, overlooked private and hybrid approaches, and did not establish a systematic, broad approach across all four categories.

Third, the paper breaks new ground by developing the broader context for the four regulatory categories that impact the choice, design, and effectiveness of each regulatory approach. That is, the choice of bycatch mitigation approach and specific policy instruments within each approach does not occur within a vacuum, but rather within a specific fishery context. The type of fishery - gear, target and bycatch species, fleet and vessel characteristics, scale of production, markets, monitoring and enforcement capacity, quantity and quality of available information, potential for bycatch-reducing technology, transboundary species, regulatory and management structure, and other factors affect the approach to bycatch management and appropriate policy instruments.

The paper is organized as follows. Section "Mitigation Hierarchy As a Framework" presents the mitigation hierarchy framework, including discussions on no net loss as an objective and bycatch mitigation impacts that account for impact equity. Section "Basic Regulatory Approaches to Bycatch Mitigation" presents four basic bycatch mitigation approaches. Section "Incentive-Based Policy and Policy Instruments" addresses the incentive-based approach, including pricing bycatch and direct and indirect incentives. Section "Direct and Incentive-Based Regulation" compares direct and incentive-based regulation. Section "Interactions Between Private Solutions and IncentiveBased Policies" develops the potential interactions between private solutions and incentive-based regulation. Section "Broader Context Shaping Choice and Performance of Policy Approach" develops the broader context shaping the choice and performance of the different policy approaches. Section "Equity and Fairness" raises the issues of equity and fairness in bycatch mitigation.

\section{MITIGATION HIERARCHY AS A FRAMEWORK}

Bycatch mitigation and the ecosystem-based approach to fisheries management are more than biological and technical issues. They also include modifying behavior and decisions made by producers (vessel owners/operators and crew, processors, distributors, retailers) and consumers to account for the biodiversity and ecological impacts of their decisions.

The mitigation hierarchy $(\mathrm{MH})$ (Business and Biodiversity Offsets Programme $[\mathrm{BBOP}]$, 2012) provides an overarching conservation framework for marine biodiversity conservation in general, and is particularly useful for addressing bycatch (Lent and Squires, 2017; Milner-Gulland et al., 2018; Squires and Garcia, 2018; Squires et al., 2018; Booth et al., 2019a; Arlidge et al., 2020b). The $\mathrm{MH}$ provides a framework for defining measurable goals and structuring available knowledge of potential management measures to achieve these goals (MilnerGulland et al., 2018; Booth et al., 2019a). The MH in the bycatch context is as follows: (1) Avoid bycatch; (2) Minimize bycatch when it cannot be avoided; (3) Restore or rehabilitate bycatch onsite when it cannot be minimized; and (4) Implement biodiversity offsets for the same species and stock (or habitat) as a last resort to address the residual from the first three steps.

The first three steps in the $\mathrm{MH}$, generally implemented in that order, constitute what could be called conventional conservatory mitigation (Squires and Garcia, 2018; Squires et al., 2018). They aim to restore the biodiversity to its predisturbance baseline or No Net Loss in biodiversity (NNL) or any other agreed "healthy state." (Here we abstract from definition, measurement, and the actual baseline chosen, including the issue of "shifting baselines," Kahn and Friedman, 1995; Pauly, 1995; Papworth et al., 2009). Avoidance entails measures to reduce the probability of encounter between potentially harmful gear and potential bycatch by separating fishing activity from individuals or stocks of concern (Arlidge et al., 2020b). Examples include no-fishing areas, deployment restrictions on fishing gear, and dynamic or static time-area closures (Hobday et al., 2013; Kaplan et al., 2014; Little et al., 2015; Maxwell et al., 2015; Lent and Squires, 2017; MilnerGulland et al., 2018; Squires and Garcia, 2018). Fisheries subject to avoidance through time-area closures include the Hawaii shallow-set pelagic longline (Curtis and Hicks, 2000; Chakravorty and Nemoto, 2001) and California drift gillnet swordfish fishery (Janisse et al., 2010; Gjertsen et al., 2014), the tropical tuna purse seine fishery of the Eastern Pacific Ocean (through "El Coralito") (Hall and Roman, 2013), and the southern and eastern scalefish and shark fishery (Australian Fisheries Management Authority [AFMA], 2009).

Step 2 in the $\mathrm{MH}$, minimization, reduces bycatch through, for example, reductions in effort, technology standards, or bycatch reducing technological change that alters selectivity. Examples include use of circle rather than J-hooks with shallow-set pelagic longlines targeting swordfish to minimize sea turtle bycatch (Watson et al., 2005), bycatch reduction devices for demersal trawl gear (Wakefield et al., 2016), nylon leaders for shark bycatch in pelagic longline fisheries (Ward et al., 2008; Booth et al., 
2019b), hook depth (Shiode et al., 2005), type of hook and position of hook in water column for elasmobranch species in pelagic and coastal fisheries (Afonso et al., 2011), Tori lines for pelagic longline fisheries seabird bycatch (Gilman et al., 2005, 2019), the design of fish aggregating devices (FADs) to reduce bycatch of pelagic sharks (Dagorn et al., 2012b; Restrepo et al., 2017), or targeting of bigger tropical tuna schools (Dagorn et al., 2012a). Other examples include use of narrower nets in demersal gillnet fisheries to reduce sea turtle bycatch rates (Price and Van Salisbury, 2007; Gilman et al., 2010) and longlines raised off the bottom for sharks and rays (Favaro and Côté, 2015). Modification to gill net size and tension can increase selectivity of certain species and life-history stages with meshing and entanglement (Thorpe and Frierson, 2009; Harry et al., 2011). Turtle Excluder Devices (TEDs) minimize sea turtle bycatch by shrimp trawls (Crowder et al., 1994).

In the third step in the $\mathrm{MH}$, restoration or remediation strategies facilitate live release of individuals, their safe return to the sea, and their post-release survival (Booth et al., 2019a). For example, line cutters to cut hooked sea turtles in pelagic longline fisheries reduce post-hooking mortality (Gilman et al., 2006; Gjertsen et al., 2010; Dutton et al., 2011). On-board handling of caught elasmobranchs before return to sea (Booth et al., 2019b) and at-sea release of dolphins while retrieving nets with Eastern Pacific tuna purse seine vessels (Hall and Roman, 2013; Hall et al., 2017; Gilman et al., 2019).

The last step of the $\mathrm{MH}$ aims to compensate for part or all of the residual impact that remains after implementing the first three steps by addressing impacts to the same bycatch species and stock, either in the same ecosystem or in the global ecosystem. Early discussion of fisheries bycatch and offsets are found in Worldfish Center (2004), Wilcox and Donlan (2007), Dutton and Squires (2008, 2011), Janisse et al. (2010), Pascoe et al. (2011), Gjertsen et al. (2014), and Quigley and Harper (2006) discuss salmon habitat offsets. Van Dover et al. (2014) discuss deep-sea environments. Examples include protection of sea turtle nesting sites (Dutton and Squires, 2008, 2011; Janisse et al., 2010; Dutton et al., 2011; Gjertsen et al., 2014) and sea bird rookery sites (Wilcox and Donlan, 2007; Pascoe et al., 2011) or purchases of gear by outside interests for fishers to minimize bycatch in fisheries from fleets outside the fishery subject to regulation (Gjertsen et al., 2010).

\section{Is the No Net Loss (NNL) Objective Appropriate?}

The $\mathrm{MH}$ aims for NNL or even a net gain in biodiversity, for the stock or population of bycatch species. NNL is sometimes Maximum Sustainable Yield (MSY), which is often required by law (Wolf et al., 2015; Squires and Garcia, 2018). In other instances, some predetermined baseline serves as the NNL.

No net loss in the absence of a required MSY, however, does not necessarily generate the optimum level of producer and consumer benefits (hereafter social welfare) when biodiversity, or more specifically bycatch and offsets, are considered as a public good (Kotchen, 1999; Vicary, 2000). Just to be clear, bycatch reduction is the public good that is provided by fishery operators, and similarly, offsets are a public good that are provided by fishery operators or other parties. A public good is one available to all society without diminishing the amount available and is typically privately underprovided since not all benefits can be captured by the provider.

No net loss equates to an a priori level of social welfare, or baseline, that only coincidentally gives NNL. Bycatch reduction, or more generally offsets and biodiversity, is not only a public good, but it is only one contributor to social welfare (which accounts for all market and non-market costs and benefits impacting society). For example, the NNL objective can lower social welfare by not conserving sufficient bycatch if the bycatch stock requires rebuilding. The NNL objective can also lower social welfare if it restricts target catch to such an amount that the foregone social benefits out-weigh the social benefits of bycatch mitigation to NNL. NNL can also lower social welfare when producer benefits are diminished due to lower commercial landings. Whether net consumer welfare decreases (from less consumption) or increases (from conservation) depends upon society's valuation of the public good component. NNL can further lower social welfare if it constrains offsets to a sub-optimal level (Kotchen, 1999). Both social welfare and bycatch can decline when the NNL objective requires unilateral bycatch reduction of a transboundary bycatch stock, lowering producer and consumer benefits in the country of regulation and shifting production of the target and bycatch species to other, unregulated countries with higher bycatch rates (Helvey et al., 2017). Such conservation, production, and consumption "leakages" occurred in the Hawaiian shallowset pelagic longline fishery for swordfish when complete avoidance (closure) transferred production to unregulated highseas swordfish fleets with higher bycatch rates (Sarmiento, 2006; Rausser et al., 2009). The increased production was imported back into Hawaii as an inferior frozen rather than fresh product, thereby lowering consumer welfare, and the reduced Hawaiian catch and processing lowered producer welfare in Hawaii.

The NNL objective and its implementation also implicitly have distributive impacts that can disproportionately impact local and lower-income fishers (Booth et al., 2019a; Griffiths et al., 2019a,b). Avoidance, for example, can disproportionately lower such fishers' production, contributing to an inequitable impact and lower social welfare, particularly if society accords such fishers greater social importance. Compliance can then suffer, and without sufficient monitoring and enforcement, bycatch can even increase, or effectiveness of offsets could decline say through lower local community monitoring and protection. NNL can be subject to the requirement that people - especially project-impacted - are no worse off, and preferably better off, i.e., the Pareto Principle (Griffiths et al., 2019a,b). The overall bycatch objective can account for fishers, especially small-scale and lower-income, more dependent for income and food security, to have a net negative impact on the bycatch stock (satisfying no worse off), provided the gains and losses across all fisheries combine to achieve the bycatch objective (Booth et al., 2019a). An analogous issue arises with MSY compared to Optimum Yield that also accounts 
for the greatest overall benefit to the national economy and considers qualification by relevant economic, social, or ecological factors (OECD, 2006).

In lieu of NNL, the bycatch reduction objective can be defined in net social welfare gain, population stability, population recovery, sustainability or simply catch minimization, depending on what is practical given budgetary and operational constraints (Booth et al., 2019a). Much like Optimum Yield, the goal can be further broadened to account for ecological factors, overall social welfare, and distributional impacts on producers and consumers. For example, a target or even bycatch species may constitute the major protein source for low-income consumers, and the impact of lower fish consumption can adversely and significantly impact their diet, potentially require substitution to higher-cost protein sources (if at all), thereby lowering consumer welfare. More broadly, food security and poverty reduction (Béné et al., 2016; Booth et al., 2019a) require incorporation into the bycatch reduction goal, particularly in low-income countries and with artisanal fisheries. An unanswered question, analogous to single-species management, is whether a sustainability constraint of NNL pertains to each species, in which case weak stockspecies management issues arise for multispecies (target and bycatch) species.

In sum, NNL may or may not be the appropriate objective for society, and each case under consideration requires weighing the pros and cons for a bespoke approach. Moreover, the issue is not just NNL "level" but the conservation method by which it is achieved and the equity and fairness of the process and distributive impacts.

\section{Least-Cost Bycatch Reduction}

Least cost or cost-effective bycatch reduction minimizes the cost of a given level of bycatch reduction (Dutton and Squires, 2008; Gjertsen et al., 2010, 2014; Pascoe et al., 2010, 2011; Gjertsen, 2011; Innes et al., 2015; Lent and Squires, 2017; Squires and Garcia, 2018; Squires et al., 2018; Booth et al., 2019a; Arlidge et al., 2020b). It can be extended to the entire $\mathrm{MH}$ (Squires and Garcia, 2018; Squires et al., 2018; Booth et al., 2019a; Arlidge et al., 2020a,b). The least-cost MH minimizes costs across and within $\mathrm{MH}$ steps and bycatch reduction channels. The least-cost $\mathrm{MH}$ allows the maximum possible bycatch reduction for a given conservation budget and mitigates fisheries bycatch consistent with given targets, guidance in the Law of the Sea, Regional Fisheries Management Organizations, national fishery management authorities, and measures under the Convention on Biological Diversity. Through least-cost implementation, the $\mathrm{MH}$ also enables socioeconomic trade-offs to be explicitly incorporated into decisions (Squires and Garcia, 2018; Booth et al., 2019a).

\section{Equitable Bycatch Reduction}

Bycatch reduction can be extended to account for equity through the use of social distribution (welfare) weights $\omega_{i}$ (Little and Mirrlees, 1974). In principle, the relevant parties are not just those regulated but all parties that are impacted, such as low-income consumers deprived of a food source and food security. Impacted parties also include fishers outside of the regulated fishery that are impacted by spillovers from the regulated fishery, such as regulated fishers impacted by avoidance that now fish in another fishery. In practice, the parties of concern may be limited to those of the regulated fishery.

Social distribution weights for Party $i, \omega_{i}$, and equityadjusted bycatch mitigation and equity-adjusted least-cost bycatch mitigation are defined as follows. Let $\omega_{i}=\left[\frac{\bar{Y}}{Y_{i}}\right]^{\eta}$ for Party $i$, where $Y_{\mathrm{i}}$ denotes per capita income for $i, \bar{Y}$ denotes mean per capita income of all parties $N$, and $\eta$ denotes a progressivity parameter (elasticity of social marginal utility of income). $\eta>(<) 1$ makes $\omega_{\mathrm{i}}$ more (less) progressive. Let $B_{\mathrm{j}} / C_{\mathrm{j}}$ denote the least-cost ratio for bycatch $B_{\mathrm{j}}$ in $\mathrm{MH}$ step $j$ divided by the cost of bycatch mitigation in step $j C_{\mathrm{j}}$, where the ratio is equalized across steps for least-cost bycatch mitigation: $B_{\mathrm{j}} / C_{\mathrm{j}}=$ $B_{\mathrm{k}} / C_{\mathrm{k}} j, k=1,2,3,4, j \neq k$ (Squires and Garcia, 2018). Then, $\omega_{\mathrm{i}}\left[B_{\mathrm{j}} / C_{\mathrm{j}}\right]$ gives greater weight to least-cost bycatch reduction for income groups in step $j$ in which $Y_{i}<\bar{Y}$. Equalizing across all four steps $j, k, j \neq k$, gives: $\omega_{\mathrm{i}}\left[B_{\mathrm{j}} / C_{\mathrm{j}}\right]=\omega_{\mathrm{i}}\left[B_{\mathrm{k}} / C_{\mathrm{k}}\right]$ Without least-cost consideration, bycatch mitigation with equity consideration for lower-income or close proximity groups, as in Griffiths et al. $(2019 \mathrm{a}, \mathrm{b})$ is $\omega_{\mathrm{i}} B$, where here $B$ denotes biodiversity impacts in general.

\section{Offsets}

Offsets, when applied prior to the final residual step of the $\mathrm{MH}$, are a public good (Kotchen, 1999) that become an incentivebased policy substitute for avoidance and minimization (Lent and Squires, 2017; Squires and Garcia, 2018; Squires et al., 2018; Milner-Gulland et al., 2018). For eligible species, offsets can be used as an incentive-based policy instrument earlier in the mitigation hierarchy to compensate for any negative impacts through off-site conservation actions that improve the status of the affected bycatch (same species and stock) elsewhere. Bycatch mitigation costs should fall, freeing up scarce conservation budgets for other needs, or benefitting fishers as the foregone target catch and revenues should fall as less avoidance may be required.

\section{BASIC REGULATORY APPROACHES TO BYCATCH MITIGATION}

The fundamental regulatory approach to bycatch mitigation, and biodiversity conservation in general, through the MH may be binned into four general categories:

(1) Private solutions;

(2) Direct regulation;

(3) Incentive-based measures;

(4) Hybrid solutions.

Each of these approaches will be explored in turn in the sections below.

\section{Private Solutions}

Private solutions include voluntary and private negotiation between producers incurring bycatch and other private parties, 
intrinsic motivation, and moral suasion. Intrinsic motivation refers to behavior/activity coming from within the person for its own sake rather than the desire for some external reward. Intrinsic motivation contrasts with extrinsic motivation, which is engaging in a behavior in order to earn external rewards or avoid punishments (Gneezy et al., 2011; Young, 2015). Intrinsic motivation includes social and personal norms of conservation and altruism.

Moral suasion can be an important instrument to align individual and public interests (Romans, 1966). Monetary costs of moral suasion are typically small, they are quickly implemented, and can complement economic incentives or direct regulation (Bos et al., 2020). By affecting social norms or adherence to them, moral suasion is expected to contribute to bycatch reduction and to increase compliance.

Examples include negotiations and voluntary agreements such as the United States west coast groundfish fishery case discussed below. [See Gneezy et al. (2011), Bowles and PolaníaReyes (2012), Kotchen (2013), Segerson (2010, 2013), Young (2015), and Farrow et al. (2017) for general discussions of voluntary and private environmental regulation]. Credible threats, such as formal public regulation, can incentivize voluntary bycatch reduction (Segerson, 2013). Credible threats of embargoes and trade measures can also be effective, such as with the tuna-dolphin and shrimp-sea turtle issues (Joyner and Tyler, 2000).

Another example is the voluntary program reducing bycatch of river herring, blueback, herring, and American shad in the northwest Atlantic mid-water trawl fishery targeting Atlantic herring and Atlantic mackerel through an industry, state government, and university partnership (Bethoney et al., 2017). Potential public regulation provided the credible threat that motivated the voluntary program to stave off such regulation. In the United States, a voluntary program facilitates the donation to foodbanks of salmon bycatch in the Bering Sea-Aleutian Island trawl fishery (Clucas, 1997; Watson et al., 2020). The Alaskan groundfish fishery employs a voluntary program to reduce halibut bycatch (Fina, 2017).

Bycatch policy can also be influenced by intrinsic motivation that is inherent in societies, communities, and individuals. Intrinsic motivation may be particularly important in economies that are less market-centric and are more characterized by noneconomic relationships. Intrinsic motivation may be especially important for bycatch in small-scale and artisanal fisheries. Social networks can impact intrinsic motivation (Alexander et al., 2020; Arlidge et al., 2020a,b). Social norms can be classified as folkways, mores, taboos and laws (Young, 2008, 2015). For example, customary taboos that temporarily close coral reef areas to fishing have long been practiced in Solomon Islands (Foale and Manele, 2004; Foale et al., 2011). There is disagreement on whether fishing taboos (and customary marine tenure) are primarily intended for management between social groups or to sustain food security from fisheries (Johannes, 1978). Taboo on a clan reef may be declared as a mark of respect for the death of a prominent clan member, to protect sacred sites, or to prepare for a feast by allowing the short-term replenishment of fish (Abernethy et al., 2014).
Social norms may impact compliance to bycatch regulation, whether direct or incentive-based. ${ }^{1}$ Bycatch-regulated vessels may be motivated to comply with regulations, and even to go beyond literal compliance, not only fear of legal sanctions but also by social pressures and norms. (See Thornton et al., 2009 for trucking). Along similar lines, voluntary bycatch reduction may arise due to credible regulatory threats, but additional compliance may arise due to social norms. Larger and more commercialized seafood firms may respond more positively to bycatch regulation than small firms, since they are more visible and more closely scrutinized by regulators, consumers, and advocacy groups and are more concerned with brand and social reputation.

\section{Direct Regulation}

Direct regulation, also called top-down or command-andcontrol, focuses on mandating specific behavior through standards on technology, process, and performance which address in particular the avoidance and minimization steps of the MH. A standard is a limitation on behavior on a producer, such as a performance standard on the outcome of production as with a catch quota or limit (Helfand, 2013). Bycatch can be tackled through top-down, direct regulation by a fishery management authority, government, or Regional Fisheries Management Organization. Direct regulation can be accomplished through combination of technology, process, and performance standards.

A technology standard specifies bycatch reduction technologies or production processes that producers must implement for avoidance or minimization. Examples include the prohibition of sundown sets to reduce dolphin mortality when setting on dolphins to capture large yellowfin tunas in the Eastern Pacific Ocean (Gjertsen et al., 2010; Hall et al., 2017), discarding offal on the opposite side of the vessel from which gear is released and required use of Tori lines on longline vessels (seabirds) (Gilman et al., 2014, 2016), selectivity requirements for gear such as mesh size, use of circle hooks with mackerel-type bait rather than J-hooks with squid bait (sea turtles) (Kerstetter and Graves, 2006; Reinhardt et al., 2017), bycatch reduction devices on trawl nets (Melli et al., 2020), and the use of pingers on drift gillnets (marine mammals, sea turtles) (Gilman et al., 2010). Technology standards may change as technology changes. One critical issue with technology standards is that they tend to remove incentives for fishery operators to find other ways to reduce bycatch and they can also freeze bycatch-reducing technology in place.

A process standard requires that vessels satisfy limits or conditions on the process of fishing to achieve avoidance or minimization. Examples include bycatch avoidance

\footnotetext{
${ }^{1}$ An reviewer suggested that the role of social license to operate can be included in the discussion on intrinsic motivation and especially social norms. Bycatch is often associated with reduced social license, which in turn affects social norms. Social license (to operate) can be defined as existing when a project has the ongoing approval within the local community and other stakeholders, ongoing approval or broad social acceptance and, most frequently, as ongoing acceptance (Prno and Slocombe, 2012). Social license thus constrains vessels and supply chain firms to meet the expectations of society and to avoid activities that societies deem unacceptable rather than compliance with legal requirements (Thornton et al., 2009). The relationship between social license to operate and social norms is complex and beyond the scope of this paper.
} 
through time-area closures, including Marine Protected Areas (Di Lorenzo et al., 2020), such as the time-area closure to reduce bycatch of harbor porpoises in the Gulf of Maine sink gillnet fishery (Murray et al., 2000) and another that is aimed to reduce bycatch of Atlantic cod and yellowtail flounder in the Georges Bank scallop fishery (Keith et al., 2020). Limits on vessel size or trip length or frequency are another process standard. Dynamic ocean management, such as the Hawaii Turtle Watch program (Howell et al., 2008), is another form of process standard (Hobday et al., 2013; Little et al., 2015; Maxwell et al., 2015).

A performance standard requires vessels meet a standard to minimize bycatch, such as a bycatch quota, while allowing the vessels to choose any appropriate method to meet that standard subject to inherent legal limits such as in the Pacific coast United States groundfish trawl fishery (Holland and Martin, 2019). New Zealand manages bycatch of Hooker's sea lions in the arrow squid trawl fishery through quotas on bycatch (Bache, 2003). Performance-based permits are a related policy option, involving issuing permits only to those who meet bycatch standards (Gjertsen et al., 2010).

Standards can be uniform across all producers and consumers or differentiated by types of producers and consumers. Performance standards on bycatch, such as bycatch quotas, may be differentiated by vessel size class. For example, in the tropical tuna FAD fishery the major determinant of species and size caught is vessel's capacity (size and use of satellite buoys, echo-sounders, and supply vessels) (Guillotreau et al., 2011). Performance standards through avoidance can impact a broad range of fleets, generating diverse responses through fishing effort redistribution, such as with a closure of the United Kingdom Exclusive Economic Zone for a diverse group of French vessels (Dépalle et al., 2020). Another example is sea turtle bycatch quotas for Hawaii pelagic longline shallow sets (swordfish) but not deep sets (bigeye tuna). Differentiated standards can be designed to more closely match producers' ability to reduce bycatch, and thereby could lower costs of compliance.

Standards can be absolute or relative (Helfand, 2013). Standards are defined, either implicitly or explicitly, as a rate, such as per unit of time, area, effort, or catch. If the measure in the denominator is completely exogenous to the process, the standard is absolute, such as an absolute limit on bycatch or effort per unit of time (time is exogenous). An absolute standard limits total quantity of bycatch. A relative standard, also known as rate-based or intensity standard, is a standard per unit of catch, bycatch, effort, habitat, or other measure over which the regulated entity has some control. Thus, if the denominator can be controlled such as bycatch per unit of target catch or effort, the standard is relative and does not have a limiting total quantity. A relative performance standard example is bycatch per unit of input (effort), per unit of gear (e.g., per thousand hooks), or per unit of target species catch. If a relative standard applies equally to vessels of different sizes or for example bycatch rates - a uniform standard - a relative standard will require proportionately equal bycatch reduction from all vessels. A differentiated relative standard distinguishes the standard by vessel size class or some other distinguishing feature. The ratio defining the relative standard can be uniform or differentiated and can be adjusted over time.

In sum, regulatory policy instruments can be based upon the state of technology, performance or outcomes of the bycatch mitigation, or on the process of production, transportation, processing, and distribution. Technology standards tend to be easily understood and often are readily accepted. Processcentered policy instruments affect the choice and state of technology and the choice and use of inputs in production. Performance-based approaches generally provide producers greater flexibility in meeting bycatch reduction goals than those based upon process. Performance-based approaches tend to create stronger and more direct economic incentives because they directly address the desired policy outcome. Processcentered incentives are more indirect because only some of the inputs and practices are regulated, and the relationship between the regulated inputs and the expected outputs can be indirect and more uncertain. Process-centered incentives are consequently weaker because they are more indirect. Nonetheless, performance-centered policy instruments may be more difficult and costly to monitor and enforce than processcentered approaches, especially due to at-sea production.

\section{Incentive- or Market-Based Measures}

Incentive-based (also called market-based) measures place a price bycatch and thereby give residual bycatch a cost. This bycatch cost in turn is incorporated into the price of the catch of target species and any bycatch that already may be sold (and hence has an existing price). Pricing bycatch then increases the cost of production, which in turn incentivizes changes in producer and consumer behavior and decision-making to reduce the scale and mix of bycatch (Goulder and Parry, 2008).

Economic incentives, increasingly used to address pollution, climate change, terrestrial conservation, water, and energy efficiency, have potential for greater application to bycatch reduction and marine biodiversity conservation (Hall, 1996; Dutton and Squires, 2008, 2011; Gjertsen et al., 2010, 2014; Pascoe et al., 2010, 2011; Dutton et al., 2011; Segerson, 2011; Innes et al., 2015; Walmo et al., 2016; Lent and Squires, 2017; MilnerGulland et al., 2018; Squires and Garcia, 2018; Squires et al., 2018; Booth et al., 2019a,b; Arlidge et al., 2020b). As this paper emphasizes, however, economic incentive-based bycatch mitigation is context-specific in its design, use and effectiveness. Incentive-based bycatch reduction can apply to any step of the $\mathrm{MH}$, including offsets to address residual bycatch after the first three steps of the MH (Dutton and Squires, 2008; Pascoe et al., 2011; Lent and Squires, 2017; Milner-Gulland et al., 2018; Squires and Garcia, 2018; Squires et al., 2018; Booth et al., 2019a; Arlidge et al., 2020b).

Incentives can be positive or negative. Positive incentives reward producers for reducing bycatch, such as through an ecolabel, or subsidies which can be cash or in-kind and direct or indirect. An in-kind example is credits for days fishing or access to areas closed to fishing if certain bycatch reduction measures are implemented. Negative incentives penalize producers for bycatch, such as direct taxes (Wilcox and Donlan, 2007; Dutton and Squires, 2008, 2011; Gjertsen et al., 2010; Pascoe 
et al., 2010; Dutton et al., 2011; Segerson, 2011; Innes et al., 2015; Booth et al., in press) or in-kind and indirect, such as loss of access to a fishing ground or fewer days to fish. Full retention of bycatch forms an implicit tax, because it displaces target catch and revenue (Chan et al., 2014). Tax receipts applied to further bycatch reduction form a "double-dividend" bycatch tax (Dutton and Squires, 2008; Gjertsen et al., 2010; Pascoe et al., 2010; Booth et al., In press). As an example, the Federation of Seafood Harvesters (FISH), the industry association of the California drift gillnet fishery for swordfish, voluntarily initiated payments in the Fall of 2004 to the Asociacion Sudcaliforniana de Proteccion al Medio Ambiente y la Tortuga Marina (ASUPMATOMA), a Mexican conservation group, to aid their Pacific leatherback turtle (Dermochelys coriacea) recovery efforts (Janisse et al., 2010). FISH financed the payments for offsets by a voluntary tax. The three major United States tuna processors, operating through the International Seafood Sustainability Foundation (ISSF), voluntarily tax themselves US\$1/ton of landed longlinecaught tuna to finance offsets for sea turtle bycatch (Squires et al., 2018; Pakiding et al., 2020).

Individual transferable quotas (ITQs) for bycatch (Boyce, 1996; Bisack and Sutinen, 2003; Gjertsen et al., 2010; Hannesson, 2010; Singh and Weninger, 2014; Hall et al., 2017; Miller and Deacon, 2017) are another incentive-based policy instrument, where bycatch reduction and selling or otherwise transferring ITQs confers a benefit and positive incentive through revenues earned and buying ITQs to cover bycatch not covered by quota creates a cost and negative incentive. Trade of bycatch ITQs may be tailored and when applied to weak stock species each fisher may be required to hold sufficient rights to cover any bycatch (Miller and Deacon, 2017). An advantage to ITQs is that they counter the "race-to-fish" associated with an overall bycatch TAC.

Incentive-based policy instruments can be a combination of penalty-and-reward measures, a two-part policy instrument (Fullerton and Wolverton, 1999; Segerson, 2011; Kotchen and Segerson, 2019). A penalty (indirect tax), such as fewer fishing opportunities for not avoiding or minimizing, can be coupled with a reward (indirect subsidy), such as extra fishing opportunities for avoiding or minimizing (Segerson, 2011; Kotchen and Segerson, 2019). The penalty and reward do not have to be equal (Fullerton and Wolverton, 1999; Segerson, 2011; Kotchen and Segerson, 2019). On average over time if the penalties and rewards are correctly set, the quota should just be met and penalties should just match rewards (Fullerton and Wolverton, 1999; Segerson, 2011; Kotchen and Segerson, 2019). The Scottish credit scheme is designed to reduce cod bycatch through a penalty-and-reward system of days (Scottish Government, 2011). The Bering Sea pollock mothership fleet employs a voluntary credit scheme to reduce salmon bycatch (Mize, 2014).

A deposit-refund system for fishing gear and equipment, which can reduce "ghost fishing" is another example of these twopart policy instruments, which can also address the uncertainty about the bycatch reduction (Jensen et al., 2017).

Incentive-based policy can follow either the Polluter Pays Principle (PPP) or the User (Beneficiary) Pays Principle (UPP). Biodiversity offsets provide an example of PPP, since producers, who create the bycatch, must pay for the offsets. Conservatory offsets, applied earlier in the $\mathrm{MH}$ than compensation, are incentive-based (Squires and Garcia, 2018; Squires et al., 2018). Payments for ecosystem services provide an example where entities concerned about bycatch may be willing to pay those who cause the bycatch to reduce their bycatch (Bladon et al., 2016). The BPP tends to hold in international fisheries, since there is no global institution that requires countries to reduce bycatch (although a fleet's government could require bycatch reduction due to that country's own, internal reasons).

\section{Hybrid Solutions: Bycatch Liability}

Bycatch liability is a performance-based hybrid of direct and incentive-based regulation in which parties are held liable for bycatch exceeding some baseline. Bycatch liability is typically triggered in some period by an event or condition (Lodge et al., 2019). Liability requires determining the damages that have occurred, whereas most incentive-based policy instruments raise the cost of bycatch by enough to incentivize vessel operator decision-making and behavior to reduce bycatch.

Several key challenges arise. One is defining, measuring, and monitoring the triggers with relative ease and low costs. Another concern is the transactions and information costs of reaching and enforcing agreements. A final issue is the burden of proof that involves damage to a person, community organization, etc., establishing a direct causal link between their losses and the resource user's activities.

There are two general forms of liability: strict and negligence based. A producer under strict liability is responsible for bycatch regardless of the amount of care taken to avoid bycatch (in the more legal sense of damage). A producer under a negligence rule is not held responsible for bycatch unless the producer is negligent in conducting its operations. Full compliance with existing regulations can be considered de facto evidence of nonnegligence and thereby absolve the producer of responsibility for any residual bycatch. The incentive, cost, and risk implications of imposing liability for bycatch depend upon the form of liability used (Lodge et al., 2019).

Strict liability, applying the PPP, holds producers liable for actual rather than expected costs of bycatch (Lodge et al., 2019). Under negligence liability, non-negligent producers are not liable for any residual bycatch. This implied property right, and the associated allocation of costs between society and producers, contrasts with strict liability and implies only partial implementation of the PPP. The scale and cost of production and price to target catch for non-negligent production do not incorporate the full social cost of production, including the bycatch, which is similar to the outcome under direct regulation.

\section{INCENTIVE-BASED POLICY AND POLICY INSTRUMENTS}

Incentive-based bycatch reduction policy and policy instruments create economic incentives to change the behavior and decision-making of producers to optimally reduce bycatch. 
Bycatch is reduced through altering both the bycatch-target species catch ratio (substitution effect, mix) and scale of production that reduces both bycatch and target species catch (scale effect). Incentive-based approaches similarly alter the behavior and decision-making of producers in the supply chain and consumers in terms of the mix and scale of species to process, distribute, and consume. Over a longer period, such incentivebased approaches also generate "dynamic" incentives to create, diffuse, and adopt technology that lowers bycatch relative to target catch, i.e., to increase the selectivity of fishing.

Incentive-based approaches offer a number of other advantages (Gjertsen et al., 2010; Pascoe et al., 2010; Dutton and Squires, 2011; Segerson, 2011; Innes et al., 2015; Walmo et al., 2016; Lent and Squires, 2017; Miller and Deacon, 2017; Milner-Gulland et al., 2018; Squires and Garcia, 2018; Squires et al., 2018; Booth et al., 2019a; Lodge et al., 2019). They allow vessels greater flexibility to devise solutions that creatively and cost-effectively reduce bycatch. They also allow vessels to flexibly respond to changes in market conditions, the environment, technology, and resource conditions. They allow vessels to use decentralized, privately held information that is unavailable to the management authority. For example, vessels can use their knowledge about the time of day and location of the bycatch to adjust when and where they fish for the target species. Bycatch ITQs in the United States West Coast groundfish fishery led to fishers altering the deployment of trawl gear to either gain more precise information on the location of bycatch or to exploit the differential movements of bycatch species (Miller and Deacon, 2017). Trawl fishers shifted toward night fishing, a time when bycatch species migrate up from the sea floor and thereby become less vulnerable to trawl gear, while key target species remain near the sea floor. Trawl fishers also shifted toward shorter tows to obtain higher frequency information on bycatch, enabling avoidance through a shift in location when a bycatch stock concentration is encountered. In contrast, direct regulation tends to "bind up" or constrain vessels, and thereby restrict vessels' ability to respond to these changes. This inflexibility tends to raise production costs, by imposing uniform bycatch reduction regulations on a fleet with many differences among vessels, captain and crew skills, and in how they fish.

Individuals operating in groups of vessels sufficiently small to devise and self-manage their own bycatch reduction scheme may be more able to pool risk creating insurance programs which are proven to be effective for voluntary approaches for addressing rare and stochastic bycatch (Segerson, 2011; Deacon, 2012; Holland and Jannot, 2012; Holland and Martin, 2019; Kotchen and Segerson, 2019). These small groups have greater incentives for vessels to work collectively on activities such as real-time information sharing. Disadvantages include the potential for free riding on bycatch reduction of others or they can induce the "race to fish" as bycatch limits are met.

\section{Pricing Bycatch}

When seafood prices fail to contain information about the unpriced or underpriced costs of bycatch, producers (vessels, firms in the supply chain) and consumers do not have the full information about bycatch necessary to make decisions that lead to the optimal level and mix of bycatch. These costs are unaccounted for by producers and consumers, and more generally markets and their prices. Without seafood prices incorporating these bycatch costs, both target species and bycatch are overharvested with excessive bycatch relative to target catch.

Incentive-based policy reduces underpriced bycatch by creating a market price for the bycatch that accounts for the otherwise un- or underpriced residual bycatch jointly harvested with the target catch. Fully pricing the residual bycatch associated with the target catch increases the market price for the target catch. This higher target catch price conveys information to ex-vessel markets transmitted in full or in part through the supply chain to consumer markets.

For example, a coastal community in San Jose, northern Peru, has partnered with a local not-for-profit charity to address problematic sea turtle bycatch through a trial community management cooperative that includes pricing bycatch (Arlidge et al., 2020b). The initiative intends to create direct incentives for bycatch reduction by giving price premiums to fish caught by vessels that follow best-practice bycatch reduction guidelines.

\section{Direct and Indirect Incentive-Based Approaches}

Incentive-based approaches to bycatch reduction can be direct or indirect. Direct incentives tie penalties or rewards directly to, and conditional upon, verifiable conservation outcomes (called conditionality) that otherwise would not have occurred (called additionality). Examples of direct incentive approaches include payments for ecosystem services (Bladon et al., 2016), conservation easements (Deacon and Parker, 2009), taxes and subsidies, biodiversity offsets, credits, tournaments and prizes to incentivize bycatch-reducing technological change, and property rights such as bycatch ITQs.

Indirect incentives are incentives that are only indirectly linked to conservation in general and bycatch in particular (Gjertsen and Stevenson, 2011). Indirect incentive measures change the relative costs and benefits of specific activities in an indirect way (Convention on Biological Diversity [CBD], 2020). Conservation per se is not directly tied to an economic incentive. Instead, conservation occurs as a result of the incentive. Individuals are not directly rewarded for pursuing conservation activities or achieving a conservation performance/outcome, nor are they directly penalized for degrading activities or failure to achieve conservation performance. Indirect conservation uses development initiatives and changes in business models, product markets, employment, and income opportunities to encourage local resource users to change their behavior in ways that lead to greater conservation.

The two general categories of indirect incentive-based approaches to bycatch reduction are: alternative livelihoods (integrated development projects) and community-based conservation (community resource management and community conservation). Both may be especially suitable for small-scale fisheries (Allison and Ellis, 2001). Indirect approaches may not 
always specifically target bycatch but instead both target and bycatch species.

Alternative livelihoods, such as ecotourism, direct people away from the environmentally damaging activity and toward an alternative with lower impact livelihood activities providing at least equivalent monetary and non-monetary benefits (Wright et al., 2015). As an example, community members may receive wages as patrollers or rangers of sea turtle nesting beaches to protect sites, where the wages provide on-going incentives with conditionality and additionality (Gjertsen and Stevenson, 2011; Marcovaldi, 2011; Pakiding et al., 2020). In some instances, people may simply add the alternative livelihood to their existing activities (Torell et al., 2010), precluding bycatch reduction. Incentives are not necessarily created for the community as a whole. A related approach provides capital or infrastructure to the community as a whole, such as a school. An important issue is whether incentives are on-going or one-shot and whether there is conditionality and additionality. Wright et al. (2015) review additional issues.

Eco-tourism, another type of alternative livelihood, provides benefits to all or part of the community for preserving a population, such as sea turtles. For example, the communities of Kubulau district in southwestern Vanua Levu, Fiji, created a network of 13 protected areas to address poaching threats. Together with Moody's Namena Resort, the Kubulau communities enforce no-take areas against poaching to protect important dive sites, using a surveillance system involving community fish wardens. The system is financed through dive-tag fees from dive-tourism operations, and the funds are used for community-developed, tertiary scholarships, and operational costs such as patrolling. Such broad-based programs also provide protection to sea turtles and elasmobranchs that can be subject to bycatch in other areas (Niesten and Gjertsen, 2010). The Misool Eco-Resort in Papua, Indonesia entered into a 25-year lease with the customary owners of uninhabited Batbitim island to establish a no-take zone that protects coral reefs, sea turtles, elasmobranchs, and fish, protecting populations of potential bycatch over at least part of their life history (Niesten and Gjertsen, 2010).

Community-based conservation is based upon simultaneous achieving successful conservation and development (Berkes, 2004, 2006). Community-based conservation is decentralized and entails meaningful community participation in conservation (Agrawal and Gibson, 1994). Thus, community-based conservation includes natural resources or biodiversity protection by, for, and with the local community' (Western and Wright, 1994). Community-based management can take many forms and involve many existing institutions. It is also contextual and influenced by social norms, customs, and culture. For example, community-based management in the Pacific Islands tends to involve traditional institutions, especially taboos, to implement spatial management (Abernethy et al., 2014). Customary marine tenure, an institution, can have flexible boundaries that can impact, for example, spatial management (Foale and Manele, 2004). Community-based conservation is an important component to leatherback sea turtle nesting conservation in Papua Barat, Indonesia and supports offsets (Pakiding et al., 2020). Improved nest protection has helped optimize hatchling production, but local community engagement, through activities that empower and enhance quality of life, has been to the successful increases in hatchlings.

Community-based conservation sometimes is effective and in other instances is not (Ostrom, 1990; Baland and Platteau, 1997, 2000; Berkes, 2004, 2006). For example, a widespread community approach to mariculture and fishing prohibition failed to prevent poaching within the mariculture ranch, because sanctions were ineffective (Hair et al., 2020). A network of communitybased MPAs was established in the early 2000s to conserve declining populations of bumphead parrotfish and other locally valuable fish (Hamilton et al., 2019). The populations did not decline due to sustained fishing pressure, poor enforcement of community-based management measures, and loss of fish nursery habitats due to logging.

Indirect incentive policies are potentially more sustainable than direct approaches since they do not require on-going financing, may be more consistent with social norms, may be more useful when the bycatch problem is not well defined or property rights are less clearly defined and enforced. However, indirect incentives may be 'one-shot' in nature due to frontloaded benefits without conditionality or additionality, may be in addition to rather than substitute for detrimental activity, and have unintended consequences. Communities are heterogeneous, and thus benefits and costs are not necessarily incurred in a fashion that would foster incentives for all relevant community members. This underscores the importance of front-loading community engagement in the design and implementation of alternative economic activities.

\section{DIRECT AND INCENTIVE-BASED REGULATION}

Regulation can play a critical role in enacting incentive-based approaches. Direct bycatch regulation, such as avoidance through closed areas, or minimization through bycatch limits or gear requirements, has a number of advantages. These include the known impact on producer behavior if the producer is compliant, low levels of risk for producers when the bycatch management requirements are well defined and established, and relatively low administrative costs if compliance can be easily monitored and enforced.

Direct bycatch regulation as the sole regulatory approach has a number of disadvantages that reflect information, cost, and incentive compatibility issues faced by fishery management authorities and producers. Direct regulation does not use all of the information that can potentially engage bycatch reduction options across and within steps of the MH. Direct regulation largely uses the information on bycatch mitigation held by the fishery management authority when in fact, producers hold information, sometimes quite subtle and producer-specific, that the fishery management authority does not typically know and use. This information grows in importance as producers gain experience, learn and adapt. Bycatch mitigation can entail multiple, ongoing adjustments in fishing that are taken 
individually and may have varying and even small impacts at the vessel-level but collectively can have a significant impact.

By not pricing residual bycatch, direct regulation does not add the cost of the remaining bycatch to the cost and price of the target catch (although the target catch production costs reflect the higher costs due to direct regulation). The targetcatch price and costs will typically be lower than under bycatch pricing, so that vessels are not incentivized to sufficiently reduce the scale of production and bycatch-target catch ratio. However, sufficiently impactful direct regulation raises costs by enough to reduce the scale of production to the desired level (or even below), although not in a cost-effective manner, i.e., direct costs are unnecessarily incurred by producers to meet bycatch goals. Thus, direct regulation does not impose responsibility upon producers for any bycatch that might occur despite compliance with those regulations. It implies only partial implementation of the Polluter Pays Principle, since producers do not pay the cost of residual bycatch occurring despite compliance. Direct regulation shares bycatch reduction costs between producers (for avoidance, minimization, and restoration) and those other stakeholders who also suffer from the residual loss of bycatch. By failing to engage all bycatch reduction channels across and within steps of the mitigation hierarchy and across all producers and fishing areas, bycatch will not be reduced in a fully socioeconomically and ecologically optimal way.

Direct bycatch regulation does not generate any funds for compensation of either anticipated or unanticipated bycatch. Society instead bears the full cost and the full risk of any resulting significant bycatch despite compliance. Vessel operators who stay in the fleet are making sufficient profits to remain in business, however, and consumers who can pay the higher prices are still able to consume the product.

When costs of bycatch mitigation vary across producers, uniform or "one-size-fits-all" direct regulation is not costeffective, because it does not create economic incentives to meet bycatch mitigation targets in a least-cost way. The costminimizing mitigation approaches can vary by producer, who can use producer-specific knowledge and methods. Direct bycatch regulation that is differentiated by some criteria, such as different limits according to vessel size class, could reduce the regulatory costs to vessel operators.

Direct bycatch regulation can incentivize non-compliance due to higher costs, with vessel operators engaging in actions to circumvent these regulations and other actions that ultimately hinder bycatch reduction and create economic waste. Finally, direct bycatch regulation fails to incentivize producers to exceed their regulatory requirements set through technology, process, or performance standards.

For all these reasons, reliance solely upon direct regulation to reduce bycatch is likely to fall short on several of the criteria that a fishery management authority might use in evaluating alternative policy approaches. Nonetheless, impactful direct regulation can sometimes induce more bycatch reduction than incentive-based approaches, particularly in time-critical situations.

There are also limits to incentive-based approaches due to the assumption of purely rational behavior. Thus, "Individuals may have bounded rationality, limited by cognitive resources, and employ a variety of heuristic procedures to achieve outcomes that are 'good enough' rather than truly optimal" (Conlisk, 1996). Further, a range of emotional, social, cultural and cognitive biases shape people's decisions (Cinner, 2018). Another limitation is the interaction of extrinsic motivation - economic incentives with intrinsic motivation, leading to crowding out, as discussed below. Bycatch reduction is also shaped by social networks, trust and social capital, local leadership and role models, governance and institutional structures, social norms and peer pressure, perceived legitimacy of regulations, perceived effectiveness of proposed measures, and even the skill, experience and motivation of individual fishers and captains (Booth et al., 2019b).

Economic incentive-based approaches may not always have a substantial cost advantage over direct regulation if there is little heterogeneity in costs among vessels. If incentive-based instruments have only a small impact upon target catch prices, then the failure to optimally exploit target catch reduction channels (that therefore reduce bycatch) under direct regulation may have little impact in practice. Instead, direct regulation that is tailored to the heterogeneity, such as vessel size class or area and time fished or gear type, may be superior. The relative conservation and management costs of direct and incentivebased regulation can also tip the balance one way or the other.

Policy instruments based upon market incentives more typically, although not always, create stronger bycatch reduction incentives. In some instances, direct regulation can create even stronger incentives but at a higher economic cost.

\section{INTERACTIONS BETWEEN PRIVATE SOLUTIONS AND INCENTIVE-BASED POLICIES}

Economic incentives can interact with private solutions and prosocial behavior, notably intrinsic motivation such as social norms or altruism, in positive ways, called crowding in, and in negative ways, called crowding out (Deci, 1971, 1975; Bowles, 2008; Gneezy et al., 2011; Bowles and Polanía-Reyes, 2012; Rode et al., 2015; Young, 2015; Nyborg et al., 2016; Farrow et al., 2017; Booth et al., 2019a). Economic incentives can have two effects: the standard relative price effect that makes the incentivized behavior more attractive, and an indirect psychological effect associated with intrinsic motivation. The total effect on behavioral intentions is thus comprised of two effects either reinforcing each other through crowding in or offsetting each other through crowding out.

Resumption of dolphin hunting in the Solomon Islands after a conservation agreement between local communities and a conservation group previously providing financial support to develop alternative activities may be due to crowding out. Villagers explained that stopping the hunt had brought much tension in the village, and that resuming hunting brought peace back among community members (Innes et al., 2015; Oremus et al., 2015). Overfishing by rural communities in Columbia regulated by a weakly enforced quota with a fine as evidenced by a common property resource game with the local population (Rodríguez-Sickert et al., 2008; Velez et al., 2010) 
and a comparable field experiment by rural Cambodian villagers (Travers et al., 2011).

A producer's intrinsic motivation can change in response to a change in external intervention, or a change in the perceived nature of the task or in the producer's self-perception. In some instances, a large psychological effect can crowd out the economically incentivized behavior.

Crowding out can operate through several principal channels. One channel is information. The fishery management authority (regulator) may be better informed about conservation goals than the producer (e.g., owner and/or operator of the vessel, principal). The fishery management authority, when better informed than the producer, may choose a reward level signaling the difficulty of the task and the producer's ability to complete the task satisfactorily, which could require additional economic rewards to complete the conservation. The fishery management authority may alternatively signal lack of trust in the producer's ability or willingness to reach a satisfactory conservation goal, which in turn can lower intrinsic motivation.

A second channel for crowding out occurs when extrinsic economic incentives reduce other intrinsic motives to conserve. One example is the higher personal benefit to an individual producer associated with a higher level of prosocial behavior, thereby impacting the reputational value attributed to a producer's intrinsic and extrinsic motivation. Decreasing the signal about a producer's prosocial preferences and increasing the signal about a producer's self-interest may result in lower image motivation and impaired self-esteem. (Image motivation pertains to the desire to be liked and well regarded by others and therefore depends on behavior visible to others). Offering higher material rewards may cause the indirect psychological effect to crowd out the standard price effect, depending on the extent to which the signals are public.

In sum, intrinsic motivation interacts with economic incentives in complex ways that change over time. In some instances, intrinsic motivation is more effective at reducing bycatch than economic incentives. Carefully tailored incentives can build off intrinsic motivation that enhances rather than inhibits bycatch reduction. Incentive-based policy can reinforce and shift intrinsic motivation by causing producers to first change their behavior, then shift their beliefs to conform to that behavior. The effects of incentives depend upon how they are designed, the form in which they are given (monetary and non-monetary), how they interact with intrinsic motivation, and what happens after the incentives are withdrawn. Although admittedly complex, the true cost of economic incentives should include the adverse effects of any motivation crowding out.

\section{BROADER CONTEXT SHAPING CHOICE AND PERFORMANCE OF POLICY APPROACH}

\section{Transboundary Bycatch}

Some bycatch populations are transboundary such that bycatch reduction requires multilateral cooperation or coordination across multiple parties and even multiple fishery management authorities (Barrett, 2003, 2010, 2016). This broader bycatch context is also holistic, extending beyond fishing interactions with the bycatch species to its life cycle and geographic range. Unilateral bycatch mitigation can be subject to a conservation "leakage," whereby the same bycatch population faces higher mortality in another jurisdiction due to bycatch in a different fleet (Mukherjee, 2015; Chan and Pan, 2016; Helvey et al., 2017). These leakages may be accompanied by a trade leakage, whereby the target catch is imported into the country unilaterally reducing bycatch in order to fill the consumption gap of the target species, possibly leading to increased bycatch mortality.

\section{Implications of Industry Size and Organization}

In commercial fisheries with reasonably strong and effective fishery management, bycatch reduction depends upon coordination and agency problems. Agency problems refer to attaining compliance when the producers (agents) have more information about bycatch reduction than the management authority (regulator and principal) (Vestergaard, 2010; Jensen et al., 2017). Coordination problems refer to coordinating the actions, behavior, and decision-making of producers among themselves and with the fishery management authority.

The effectiveness of bycatch reduction depends upon the number of producers, the scale of the individual businesses, and industry organization. Consider the different context of a fishery such as the large-scale tuna purse seine and longline vessels or Pollock or groundfish vessels in the United States North Pacific or North Atlantic, and most coastal fishing fleets. Bycatch reduction then also depends upon a comparatively strong and effective management authority with the capability for at-sea monitoring, control, and surveillance of catch or effort and effective enforcement and with the capability of organizing and coordinating producer behavior.

When there is a limited number of large-scale producers, bycatch reduction is simplified due to the strong coordination and lower transactions and information costs among and within large companies or other strong cooperative arrangements such as formal cooperatives or a mother ship and catcher vessels (Deacon, 2012; Kotchen and Segerson, 2019; Aceves-Bueno et al., 2020). This can lead to comparatively low transactions and information costs within and between organizational units and also with the fishery management authority. Lower costs in turn allow bycatch limits to be allocated to the large organizational units, which then self-resolve these issues. With the resulting regulatory interdependency among group members, when any member of a group contributes to improved group performance, it generates benefits for all other group members through penalty avoidance. The United States Alaskan large-scale groundfish trawl fleet, comprised a limited number of multi-vessel companies, voluntarily reduces halibut bycatch through a co-management scheme with the North Pacific Fishery Management Council (Fina, 2017). Group approaches can also promote information sharing, pooling of risks within a group, and reduce uncertainty 
(Holland and Jannot, 2012; Holland and Martin, 2019). Such regulation has the potential to be voluntary, typically under a strategic threat of formal regulation (Kotchen, 2013; Segerson, 2010, 2013; Kotchen and Segerson, 2019).

In such a decentralized system, control of catch, monitoring, compliance, and enforcement is critical, such as through a basic incentive structure. Such an incentive structure could include a penalty of a lower bycatch limit for failure to meet the objective or a reward such as a larger target catch or longer season or carryforward of bycatch limits from 1 year to the next (Segerson, 2011; Kotchen and Segerson, 2019). The comparatively limited number of organizational units lowers the costs of coordination and reduces the agency (asymmetric information) problem between the fishery management authority and the organizational units. The larger-sized firms or organizations and fewer vessel numbers means that these units can at least partially, if not fully, self-organize and coordinate bycatch reduction actions internally rather than relying upon markets and the fishery management authority to fulfill these functions (Coase, 1937). Such actions reduce the problem of differing quality and quantity of information - moral hazard - that otherwise occurs when producers only partially rather than fully fulfill the fishery management authority's intentions. Each party in a "contract" has an incentive and opportunity to gain from acting contrary to the principles laid out by the agreement. Here, producers may circumvent bycatch reduction regulations by taking advantage of loopholes or because the producers' actions are not observed or enforced.

When there are a large number of limited-scale producers, collaborative bycatch reduction becomes more complicated and expensive. There is also a greater potential for producers to fail to fully reduce bycatch according to intent of the regulations or the regulations do not completely cover all relevant bycatch possibilities (i.e., moral hazard) (Vestergaard, 2010; Jensen et al., 2017). The larger number of individual companies and vessels increases the information and transactions costs of coordinating the vessels' actions among themselves and in relation to the management authority. The vessels (which include multi-vessel companies), to the extent they can selforganize through industry associations and cooperatives, lower the costs and difficulties of coordination among themselves and with the management authority, i.e., facilitate comanagement. Nonetheless, the management authority and the regulatory structure must provide more of the coordination and absorb more of the costs of coordination, monitoring, and enforcement.

With more numerous small-scale vessels, the fishery management authority must organize more formal, intricate, and costly monitoring, control, surveillance, and enforcement compared to the first type, due to the larger number and likely greater heterogeneity of the producers. The asymmetry of information between vessels and the management authority can be sizable given the large number of spatially dispersed vessels. Markets are used rather than transactions internal to firms in the case of larger and fewer firms due to the sizable information and transactions costs of coordination among the many vessels (Coase, 1937). Non-governmental organizations (NGOs), by absorbing and lowering the costs of information and transactions of bycatch reduction, can also contribute to coordinating the different vessels to meet bycatch reduction. However, NGOs can also raise costs by introducing additional and heterogeneous perspectives into the bycatch management process. In this second case, there is a well-developed tool kit of policy instruments that can be applied, many of them incentive-based, as discussed in the next section.

In sum, the choice of regulatory approach and policy instruments depends, in part, upon the number of vessels or firms, their scale of production, and how the industry is organized (including cooperatives and centralized industry groups). The fishery management authority can often set a bycatch limit and a penalty for non-compliance (a negative incentive) or even an in-kind reward for compliance, and allow the vessels to self-organize, as long as there is sufficient monitoring, control, and surveillance. Thus, private solutions, incentivized through a strategic threat, may suffice.

\section{Information Between Producers and Consumers}

Information about bycatch is not equally available throughout the supply chain. The quality and level of bycatch information decreases from the producer through the processors, distributors and on to the consumers. Adverse selection arises when any of these involved economic agents has more bycatch information than others but for its own benefit does not reveal it to the other parties when entering into a bycatch reduction agreement, such as unrevealed greater bycatch rates than other parties and participating in a certification scheme. Moral hazard arises when any involved agents do not fully comply with say bycatch reduction requirements when it does not bear the full costs of that risky behavior. This asymmetric information does not allow socially efficient behavior and decision-making for optimal conservation for parties farther from producers (Vestergaard, 2010; Kotchen, 2013; Segerson, 2013; Jensen et al., 2017). Thus, for example, consumers were initially unaware of the dolphin bycatch associated with harvest of large yellowfin tunas in the Eastern Pacific Ocean, and as a consequence, continued to purchase canned tuna unaware of the dolphin bycatch (Ballance et al., 2021). Eco-labels, standards, certification, and information programs all intend to rectify this issue by signaling information about bycatch, although the information quality (e.g., distortions) can readily deteriorate and may not even reach producers from consumer markets or higher in the supply chain. ${ }^{2}$

\section{Bycatch Reducing Technological Change}

Bycatch-reducing technological change lowers the ratio between bycatch and target catch to better achieve the avoidance and especially minimization steps of the $\mathrm{MH}$. Examples include

\footnotetext{
${ }^{2} \mathrm{An}$ anonymous referee noted that certification can provide a price incentive to producers, but also provides a signal to consumers, affecting the social license and thereby affecting the social norms in the fishery. In theory, with better information between producers and consumers, certification may not even be necessary to achieve this.
} 
turtle excluder devices for shrimp trawlers (Crowder et al., 1994), sorting grids for groundfish trawlers or purse seiners (Broadhurst, 2000; Misund and Beltestad, 2000), dyeing pelagic longline bait blue, side-setting, and using Tori lines and weighted branch lines that sink faster to reduce seabird bycatch (Melvin et al., 2014; Gilman et al., 2016, 2020; Hall et al., 2017), the Hawaii Turtle Watch program that provides information to pelagic longline vessels on areas with sea turtle concentration (Howell et al., 2008), circle hooks rather than J hooks to reduce sea turtle bycatch encounter and post-hooking mortality with pelagic longliners (Andraka et al., 2013), non-entangling and biodegradable designs of [FADs used in tuna purse seine fisheries reduce the entanglement of sharks, sea turtles and other organisms (Moreno et al., 2016), and illuminating gill nets with chemical or battery-operated lightsticks to reduce bycatch of sea turtles, seabirds and marine mammals (Werner et al., 2006; Wang et al., 2013)].

Producers, acting in their private capacity, tend to provide bycatch-reducing technology at a level below what is optimal to society (Romer, 1986, 1990; Squires and Vestergaard, 2013b). This technology provision is subject to free riding - other parties benefit from the technology without contributing to the costs of its development and provision. This lowers the incentives to supply, through research and development, the socially optimal level of the new technology, can slow the rate of adoption and even limit the diffusion of the new technology. Governments therefore often fill the gap (Jaffee et al., 2005). Technology policy seeks to induce and finance research and development and account for the underprovision and free riding of bycatch-reducing technological change (Squires and Vestergaard, 2013b).

Nonetheless, direct involvement by industry in research and development and learning by doing does occur for bycatch reducing technological change (Hall et al., 2000; Gilman and Lundin, 2010). For example, bird-scaring Tori lines for longlining, and the backdown procedure after dolphins are captured, the Medina dolphin safety panel, deploying at least one rescuer during backdown, and carrying specified dolphin safety/rescue equipment for tuna purse seine vessels to reduce dolphin mortality in the Eastern Pacific Ocean (Hall and Roman, 2013).

Bycatch-reducing technological change (as a form of "directed technical change") can arise due to several factors (Acemoglu, 2002). The price effect on the catch side arises when the harvesting technology has lower bycatch and the target catch consequently commands a price premium over target catch with higher bycatch. An example is pole-and-line caught tuna compared to tuna caught using FADs, where the former receives a price premium for little or no bycatch. There was a concerted effort to ensure that price premium by informing consumers and retailers about the difference between pole and line vs. FAD-caught tunas. The price effect also arises on the input side when there are relatively scarce inputs, and correspondingly high input prices incentivize reduced use of this input to reduce production costs. An example is scarce, protected Chinook salmon that are bycatch to Alaskan pollock (Mize, 2014). The regulatory limits on Chinook bycatch constrain the amount of pollock that can be harvested. Protecting Chinook reduces the pollock catch, creating a high implicit price and cost (of foregone pollock catch) to the Chinook population, an input. The high implicit Chinook cost incentivizes innovation to reduce Chinook salmon bycatch.

Another factor that incentivizes research and development for bycatch-reducing technological change is the market size effect, which occurs when new technologies have a large market and more abundant inputs. An example is innovation to reduce dolphin mortality in the Eastern Pacific Ocean, since the target species, yellowfin tuna, entered into the large North American and European markets for canned tuna and there were abundant inputs of large yellowfin tuna (Gjertsen et al., 2010; Hall and Roman, 2013; Hall et al., 2017; Ballance et al., 2021). Continued access to these markets and their large volume required innovations to reduce dolphin bycatch. Alaskan Pollock also has an important market size effect given the volume and value of pollock production.

Social network effects (value of product or service increases according to number of others using it and social interactions), ideas (accumulated and new technology) and knowledge spillovers (new technology adopted by one fisher demonstrates benefits to others), and social learning (individuals are influenced by actions taken by others when information is dispersed) can be important to the adoption of new technology (Arrow, 1962; Katz and Shapiro, 1986; Romer, 1986, 1990; Jones and Romer, 2010; Squires and Vestergaard, 2013a,b, 2018; Mobius and Rosenblat, 2014; Sorenson, 2018; Alexander et al., 2020; Arlidge et al., 2020a,b). Technology can be embodied in the physical capital stock, such as a modified or new gear type (e.g., sorting grids for trawl nets), or new methods of fishing (learning by doing), such as fishing at different times of the day when there is less bycatch. Social interactions, social norms, and the number of users directly impact the type of new technology adopted and its rate of diffusion and adoption. Network scale economies and social learning create dynamic incentives that accelerate the rate of bycatch-reducing technological change (Arthur, 2009; Arlidge et al., 2020a,b).

Diffusion and adoption of new technology may be enhanced through subsidized gear or preferential access to markets (Squires and Vestergaard, 2013b; Eigaard et al., 2014). Governments or producers in one fishery can subsidize new bycatch reducing gear for producers in another fishery with bycatch on the same species and population, thereby creating an offset. A commercial fleet could finance the adoption of bycatch reducing gear by a small-scale fleet with bycatch of the same species, thereby reducing the avoidance step of the $\mathrm{MH}$ for the commercial fleet and allowing fishing that otherwise would not have occurred (Gjertsen et al., 2014).

\section{EQUITY AND FAIRNESS}

Different policies have different impacts upon equity and fairness in both process and distribution (consequences), which in turn can impact monitoring, compliance, and enforcement. Some 
policies can more inequitably and unfairly impact all or select producers and consumers than others.

The bycatch reduction policy process can be consistent with principles of equity and fairness. Bycatch reduction policy has distributional consequences, leaving some groups relatively better or worse off. Policy impacts can be assessed for consequences by equity metrics (Cowell, 2016).

The impact of differently designed policies upon equity and fairness in process and distribution can affect monitoring, compliance, and enforcement. Some impacts can be perceived as inequitable and unfair if the foregone catch and revenue from avoidance and even minimization disproportionately fall upon lower-income or otherwise disadvantaged producers and even some consumers. Moreover, benefits, whenever they are nonmarket and diffuse across a broad population or whenever there are higher prices from eco-labeling, may not be transmitted to these fishers. Low-income fishers then bear the costs but do not enjoy the benefits of bycatch mitigation, which can aggravate any inequitable impacts. The NNL objective may also disproportionately impact local and lower-income fishers and thereby contribute to an inequitable impact and lower social welfare (Griffiths et al., 2019a,b). Policies crafted using normative principles of equity and fairness and social distribution weights can ensure equity and fairness in process and distribution (consequences) (Young, 1994).

\section{CONCLUSION}

Bycatch reduction is not only a technical issue of harvesting technology and biology, but also a human issue involving behavior and decision-making by producers and consumers. Bycatch reduction also occurs within the context of different industrial and regulatory structures of fisheries, which in turn can impact the choice of basic regulatory approach - private solutions, direct regulation, incentive- (market-) based, and hybrid - and then choice of policy instruments.

There is no single "best" approach to bycatch reduction. The "best" approach almost invariably differs by the type of fishery - the species and its life history, geographical distribution (including transboundary stocks), and population status, gear, vessel numbers and ownership structure, domestic or international fishery, commercial or artisanal fishery, the fishery management authority and its governance, the importance of markets, geographical location, and legal structure of the State or Regional Fisheries Management Organization. Nonetheless, for commercial fisheries some very basic and broad conclusions can be drawn. In contrast, bycatch reduction in artisanal and small-scale fisheries remains a challenging issue, in part due to its conflation with economic development, and likely includes elements of community-based and alternative livelihoods.

The mitigation hierarchy provides an analytical framework by which to evaluate policies to mitigate bycatch. The least-cost mitigation hierarchy potentially gives greater bycatch reduction, especially when there are limited bycatch mitigation budgets. The equitable least-cost mitigation hierarchy can explicitly address distributional consequences of bycatch mitigation policies. No single policy approach or instrument is superior across all possible criteria, and the choice(s) depend upon each individual case. The "best" approach on paper may not be feasible, and a "second-best" approach that is practicable may then be preferred.

Bycatch reduction is comprised of multiple components requiring specific regulations or policies. When combining instruments, however, the fishery management authority should consider whether the different approaches being combined form substitutes or complements. Policy instruments that are substitutes can create redundancies without any bycatch reduction, which also raises costs and can even be counterproductive. Combining approaches that are complementary can lead to a better overall outcome than use of a single approach in isolation.

Uncertainty and timing are typically underappreciated but often critical to bycatch reduction. Uncertainty arises in determining who are the winners and losers, which can delay implementation of bycatch policy instruments until the results are more clearly sorted out (Libecap, 2014). Benefits are often more uncertain and enjoyed further in the future than more immediate and certain costs. Uncertainty can lead to waiting until more information is available before adopting incentivebased policy instruments or bycatch-reducing technology. Compounding uncertainty over the size and distribution of net benefits is the time of response for the bycatch population. A slowly rebounding population can delay compensation or rewards to fishers adopting bycatch reducing policy instruments that have serious costs in foregone target catch and revenue or have sizable costs in adaptation (such as fishing in another area). Fishers facing immediate costs, such as vessel loan payments, may not be able to readily adapt.

Designing and implementing workable solutions to bycatch clearly presents a challenge for fishery managers and stakeholders. Nevertheless, this work is critically important as bycatch is a loss to society and in some cases, can cause extinction. A multidisciplinary approach conducted in collaboration with the fishing community can provide the widest possible array of options for mitigating bycatch whilst maintaining a viable fishery.

\section{AUTHOR CONTRIBUTIONS}

All authors listed have made a substantial, direct and intellectual contribution to the work, and approved it for publication.

\section{ACKNOWLEDGMENTS}

The views expressed are not necessarily those of US NOAA Fisheries, the International Whaling Commission, or Institut de Recherche pour le Développement. The authors thank Steve Stohs for comments but remain responsible for all remaining errors. 


\section{REFERENCES}

Abernethy, K. E., Bodin, Ö, Olsson, P., Hilly, Z., and Schwarz, A. (2014). Two steps forward, two steps back: the role of innovation in transforming towards community-based marine resource management in Solomon Islands. Global Environ. Chang. 28, 309-321. doi: 10.1016/j.gloenvcha.2014. 07.008

Acemoglu, D. (2002). Directed technical change. Rev. Econ. Stud. 69, 781-809.

Aceves-Bueno, E., Miller, S. J., Cornejo-Donoso, J., and Gaines, S. D. (2020). Cooperation as a solution to shared resources in territorial use rights in fisheries. Ecol. Appl. 30:e2020.

Afonso, A. S., Hazin, F. H. V., Carvalho, F., Pacheco, J. C., Hazin, H., Kerstetter, D. W., et al. (2011). Fishing gear modifications to reduce elasmobranch mortality in pelagic and bottom longline fisheries off Northeast Brazil. Fish. Res. 108, 336-343. doi: 10.1016/j.fishres.2011. 01.007

Agrawal, A., and Gibson, C. (1994). Enchantment and disenchantment: the role of community in natural resource conservation. World Dev. 27, 629-649. doi: 10.1016/s0305-750x(98)00161-2

Alexander, S. M., Staniczenko, P. O. A., and Bodin, Ö (2020). Social ties explain catch portfolios of small-scale fishers in the Caribbean. Fish Fish. 21, 120-131. doi: 10.1111/faf.12421

Allison, E. H., and Ellis, F. (2001). The livelihoods approach and management of small-scale fisheries. Mar. Policy 25, 377-388. doi: 10.1016/s0308-597x(01) 00023-9

Andraka, S., Mug, M., Hallm, M., Pons, M., Pacheco, L., Parrales, M., et al. (2013). Circle hooks: developing better fishing practices in the artisanal longline fisheries of the Eastern Pacific Ocean. Biol. Conserv. 160, 214-224. doi: 10.1016/ j.biocon.2013.01.019

Arlidge, W. N. S., Firth, J. A., Alfaro-Shigueto, J., Ibañez-Erquiaga, B., Mangel, J. C., Squires, D., et al. (2020a). Assessing Information-Sharing Networks within SmallScale Fisheries and the Implicatons for Conservation Interventions. Working paper, Department of Zoology, Oxford: Oxford University.

Arlidge, W. N. S., Squires, D., Alfaro-Shigueto, J., Booth, H., Mangel, J. C., and Milner-Gulland, E. J. (2020b). A mitigation hierarchy approach for managing sea turtle captures in small-scale fisheries. Front. Mar. Sci. 7:49. doi: 10.3389/ fmars.2020.00049

Arrow, K. (1962). The economic implications of learning by doing. Rev. Econ. Stud. 29, 155-173. doi: $10.2307 / 2295952$

Arthur, B. W. (2009). The Nature of Technology: What It Is and How It Evolves. New York, NY: Free Press.

Australian Fisheries Management Authority [AFMA] (2009). Southern and Eastern Scalefish and Shark Fishery (Closures) Direction No. 1. Canberra: AFMA, 38.

Bache, S. (2003). Bycatch mitigation tools: selecting fisheries, setting limits, and modifying gear. Ocean Coast. Manag. 46, 103-125. doi: 10.1016/s09645691(02)00123-0

Baland, J.-M., and Platteau, J. P. (1997). Coordination problems in local-level resource management. J. Dev. Econ. 53, 197-210. doi: 10.1016/s0304-3878(97) 00008-4

Baland, J.-M., and Platteau, J. P. (2000). Halting Degradation of Nature Resources: Is There a Role for Rural Communities?. Rome: Food and Agriculture Organization of the United Nations.

Ballance, L. T., Gerrodette, T., Lennert-Cody, C. E., Pitman, R. L., and Squires, D. (2021). Interdisciplinary Approaches to Bycatch Mitigation: Lessons from "The Tuna-Dolphin Problem". Oregon: Oregon State University.

Béné, C., Arthur, R., Norbury, H., Allison, E. H., Beveridge, M., Bush, S. R., et al. (2016). Contribution of fisheries and aquaculture to food security and poverty reduction: assessing the current evidence. World Dev. 79, 177-196. doi: 10.1016/j.worlddev.2015.11.007

Barrett, S. (2003). Environment and Statecraft. Oxford: Oxford University Press.

Barrett, S. (2010). Why Cooperate? The Incentive to Supply Global Public Goods. Oxford: Oxford University Press.

Barrett, S. (2016). Coordination vs. voluntarism and enforcement in sustaining international cooperation. Proc. Nat. Acad. Sci. U.S.A. 133, 14515-14522. doi: $10.1073 /$ pnas. 1604989113

Berkes, F. (2004). Rethinking community-based conservation. Cons. Bio. 18, 621630. doi: $10.1111 /$ j.1523-1739.2004.00077.x
Berkes, F. (2006). From community-based resource management to complex systems: the scale issue and marine commons. Ecol. Soc. 11, 45.

Bethoney, N. D., Schondelmeier, B. P., Kneebone, J., and Hoffman, W. S. (2017). Bridges to best management: effects of a voluntary bycatch avoidance program in a mid-water trawl fishery. Mar. Policy 83, 172-178.

Bisack, K., and Sutinen, J. (2003). Harbor porpoise bycatch: ITQs or time/area closures in the New England gillnet fishery. Land Econ. 82, 85-102. doi: 10. 3368/le.82.1.85

Bladon, A. J., Short, K. M., Mohammed, E. Y., and Milner-Gulland, E. J. (2016). Payments for ecosystem services in developing world fisheries. Fish Fish. 17, 839-859. doi: 10.1111/faf.12095

Booth, H., Arlidge, W. N. S., Squires, D., and Milner-Gulland, E. J. (in press). Bycatch levies could reconcile trade-offs between blue growth and biodiversity conservation. Nat. Ecol. Evol.

Booth, H., Squires, D., and Milner-Gulland, E. J. (2019a). The mitigation hierarchy for sharks: a risk-based framework for reconciling trade-offs between shark conservation and fisheries objectives. Fish Fish. 21, 269-289. doi: 10.1111/faf. 12429

Booth, H., Squires, D., and Milner-Gulland, E. J. (2019b). The neglected complexities of shark fisheries, and priorities for holistic risk-based management. Ocean Coast. Manag. 182:104994. doi: 10.1016/j.oceco aman.2019.104994

Bos, B., Drupp, M. A., Meya, J. N., and Quaas, M. F. (2020). Moral suasion and the private provision of public goods: evidence from the COVID-19 Pandemic. Enviorn. Res. Econ. 76, 1117-1138.

Bowles, S. (2008). Policies designed for self-interested citizens may undermine "the moral sentiments": evidences from economic experiments. Science 320 1605-1609. doi: $10.1126 /$ science. 1152110

Bowles, S., and Polanía-Reyes, S. (2012). Economic incentives and social preferences: substitutes or complements? J. Econ. Lit. 50, 368-425. doi: 10.1257/ jel.50.2.368

Boyce, J. R. (1996). An economic analysis of the bycatch problem. J. Environ. Econ. Manag. 31, 314-336. doi: 10.1006/jeem.1996.0047

Broadhurst, M. K. (2000). Modifications to reduce bycatch in prawn trawls: review and framework for development. Rev. Fish Biol. Fish. 10, 27-60.

Business and Biodiversity Offsets Programme [BBOP] (2012). Standards on Biodiversity Offsets. Washington, DC: BBOP.

Chakravorty, U., and Nemoto, K. (2001). Modeling the effects of area closure and tax policies: a spatial-temporal model of the Hawaii longline fishery. Mar. Resour. Econ. 15, 179-204. doi: 10.1086/mre.15.3.42629301

Chan, H. L., and Pan, M. (2016). Spillover effects of environmental regulation for sea turtle protection in the Hawaii longline swordfish fishery. Mar. Resour. Econ. 31, 259-279. doi: 10.1086/686672

Chan, V., Clarke, R., and Squires, D. (2014). Full retention in tuna fisheries: benefits, costs and unintended consequences. Mar. Policy 45, 213-221. doi: 10.1016/j.marpol.2013.10.016

Cinner, J. (2018). How behavioral science can help conservation. Science 362, 889-890. doi: 10.1126/science.aau6028

Clucas, I. (1997). A Study of the Options for Utilization of Bycatch and Discards from Marine Capture Fisheries. Remo: FAO.

Coase, R. (1937). The nature of the firm. Economica 4, 386-405.

Conlisk, J. (1996). Why bounded rationality? J. Econ. Lit. 34, 669-700.

Convention on Biological Diversity [CBD] (2020). Indirect Incentive Measures (Market Creation). Available online at: https://www.cbd.int/programmes/socioeco/incentives/indirect-info.shtml (accessed December 16, 2020).

Cowell, F. A. (2016). "Inequality and poverty measures," in Oxford Handbook of Well-Being and Public Policy, eds M. D. Adler and M. Fleurbaey (Oxford: Oxford University Press), 82-125.

Crowder, L. B., Crouse, D. T., Heppell, S. S., and Martin, T. H. (1994). Predicting the impact of turtle excluder devices on loggerhead sea turtle populations. Ecol. Appl. 4, 437-445. doi: 10.2307/1941948

Curtis, R., and Hicks, R. L. (2000). The cost of sea turtle preservation: the case of Hawaii's Pelagic longliners. Am. J. Agr. Econ. 82, 1191-1197. doi: 10.1111/00029092.00119

Dagorn, L., Filmalter, J. D., Forget, F., Amandè, J., Hall, M. A., Williams, P., et al. (2012a). Targeting bigger schools can reduce ecosystem impacts of fisheries. Can. J. Fish. Aquat. Sci. 69, 1463-1467. doi: 10.1139/f2012-089 
Dagorn, L., Holland, K., Restrepo, V., and Moreno, G. (2012b). Is it good or bad to fish with FADs? What are the real impacts of the use of drifting FADs on pelagic marine ecosystems. Fish Fish. 14, 391-415. doi: 10.1111/j.1467-2979. 2012.00478.x

Deacon, R. T. (2012). Fishery management by harvester cooperatives. Rev. Env. Econ. Policy 6, 258-277. doi: 10.1093/reep/res008

Deacon, R. T., and Parker, D. P. (2009). Encumbering harvest rights to protect marine environments: a model of marine conservation easements. Agr. Res. Econ. 53, 37-58. doi: 10.1111/j.1467-8489.2007.00429.x

Deci, E. (1971). Effects of externally mediated rewards on intrinsic motivation. J. Pers. Psychol. 18, 105-115. doi: 10.1037/h0030644

Deci, E. (1975). Intrinsic Motivation. New York, NY: Plenum Press.

Dépalle, M., Thébaud, O., and Sanchirico, J. (2020). Accounting for fleet heterogeneity in estimating the impacts of large-scale fishery closures. Mar. Resour. Econ. 35, 361-378. doi: 10.1086/710514

Di Lorenzo, M., Guidetti, P., Di Franco, A., Calò, A., and Claudet, J. (2020). Assessing spillover from marine protected areas and its drivers: a meta-analytical approach. Fish Fish. 21, 906-915. doi: 10.1111/faf. 12469

Driscoll, J., Wallace, S., Turris, B., and Mose, B. (2017). Using Individual Vessel Quotas to Manage Coral and Sponge Bycatch: The Case of the British Columbia Groundfish Bottom Trawl Fishery. Presentation to Workshop on incentivebased bycatch reduction case studies, Sète: NOAA-IRD-Ifremer.

Dutton, P. H., Gjertsen, H., and Squires, D. (2011). "Conservation of the leatherback sea turtle in the Pacific," in Handbook of Marine Fisheries Conservation and Management, eds R. Q. Grafton, R. Hilborn, D. Squires, M. Tait, and M. Williams (Oxford: Oxford University Press), 195-204.

Dutton, P. H., and Squires, D. (2008). Reconciling biodiversity with fishing: a holistic strategy for pacific sea turtle recovery. Ocean Dev. Int. Law 39, 200-222. doi: 10.1080/00908320802013685

Dutton, P. H., and Squires, D. (2011). "A holistic strategy for Pacific sea turtle conservation," in Conservation of Pacific Sea Turtles, eds P. H. Dutton, D. Squires, and M. Ahmed (Honolulu: University of Hawaii Press), 37-59. doi: 10.1515/9780824860196-005

Eigaard, O. R., Marchal, P., Gislason, H., and Rijnsdorp, A. D. (2014). Technological development and fisheries management. Rev. Fish. Sci. Aqu. 22, 156-174. doi: 10.1080/23308249.2014.899557

Farrow, K., Grolleau, G., and Ibanez, L. (2017). Social norms and proenvironmental behavior: a review of the evidence. Ecol. Econ. 140, 1-13. doi: 10.1016/j.ecolecon.2017.04.017

Favaro, B., and Côté, I. M. (2015). Do by-catch reduction devices in longline fisheries reduce capture of sharks and rays? A global meta-analysis. Fish Fish. 16, 300-309. doi: 10.1111/faf.12055

Fina, M. (2017). Alaskan Groundfish Trawl and Halibut Bycatch. Presentation to Workshop on incentive-based bycatch reduction case studies, Sète: NOAAIRD-Ifremer.

Foale, S., Cohen, P., Januchowski-Hartley, S., Wenger, A., and Macintyre, M. (2011). Tenure and taboos: origins and implications for fisheries in the Pacific. Fish Fish. 12, 357-369. doi: 10.1111/j.1467-2979.2010.00395.x

Foale, S., and Manele, B. (2004). Social and political barriers to the use of marine protected areas for conservation and fishery management in Melanesia. Asia Pac. Viewp. 45, 373-386. doi: 10.1111/j.1467-8373.2004.00247.x

Fullerton, D., and Wolverton, A. (1999). "The case for a two-part instrument: presumptive tax and environmental subsidy," in Environmental and Public Economics: Essays in Honor of Wallace E. Oates, eds A. Panagariya, P. Portney, and R. Schwab (Cheltenham: Edward-Elgar), 32-57.

Gilman, E., Brothers, N., and Kobayashi, D. R. (2005). Principles and approaches to abate seabird by-catch in longline fisheries. Fish Fish. 6, 35-49. doi: 10.1111/ j.1467-2679.2005.00175.x

Gilman, E., Chaloupka, M., Dagorn, L., Hall, M., Hobday, A., Musyl, M., et al. (2019). Robbing Peter to pay Paul: replacing unintended cross-taxa conflicts with intentional tradeoffs by moving from piecemeal to integrated fisheries bycatch management. Rev. Fish Biol. Fish. 29, 93-123. doi: 10.1007/s11160-01909547- 1

Gilman, E., Chaloupka, M., Swimmer, Y., and Piovano, S. (2016). A cross-taxa assessment of pelagic longline by-catch mitigation measures: conflicts and mutual benefits to elasmobranchs. Fish Fish. 17, 748-784. doi: 10.1111/faf. 12143
Gilman, E., Chaloupka, M., Wiedoft, B., and Wilson, J. (2014). Mitigating seabird bycatch during hauling by pelagic longline vessels. PLoS One 9:e84499. doi: 10.1371/journal.pone.0084499

Gilman, E., Chloupka, M., Bach, P., Fennell, H., Hall, M., Musyl, M., et al. (2020). Effect of pelagic longline bait type on species selectivity: a global synthesis of evidence. Rev. Fish Biol. Fish. 30, 535-551. doi: 10.1007/s11160-020-09612-0

Gilman, E., Gearhart, J., Price, B., Eckert, S., Miliken, H., Wang, J., et al. (2010). Mitigating sea turtle by-catch in coastal passive net fisheries. Fish Fish. 11, 57-88. doi: 10.1111/j.1467-2979.2009.00342.x

Gilman, E., and Lundin, C. G. (2010). "Minimizing bycatch of sensitive species groups in marine capture fisheries: Lessons from tuna fisheries," in Handbook of Marine Fisheries Conservation and Management, eds R. Q. Grafton, R. Hilborn, D. Squires, N. Tait, and M. Williams (Oxford: Oxford University Press), 150-164.

Gilman, E., Zollett, E., Beverly, S., Nakano, H., Davis, K., Shiode, D., et al. (2006). Reducing sea turtle by-catch in pelagic longline fisheries. Fish Fish. 7, 2-23. doi: 10.1111/j.1467-2979.2006.00196.x

Gjertsen, H. (2011). "Can we improve our conservation bang for the buck? Cost-effectiveness of alternative leatherback turtle conservation strategies," in Conservation of Pacific Sea Turtles, eds P. H. Dutton, D. Squires, and M. Ahmed (Honolulu: University of Hawaii Press), 60-84. doi: 10.1515/9780824860 196-006

Gjertsen, H., Hall, M., and Squires, D. (2010). “Incentives to address bycatch issues," in Conservation and Management of Transnational Tuna Fisheries, eds R. Allen, J. Joseph, and D. Squires (Hoboken, NJ: Wiley-Blackwell Publishing), 225-250. doi: 10.1002/9780813820262.ch14

Gjertsen, H., Squires, D., Dutton, P. H., and Eguchi, T. (2014). Cost-effectiveness of alternative conservation strategies with application to the Pacific leatherback turtle. Conserv. Biol. 28, 140-149. doi: 10.1111/cobi.12239

Gjertsen, H., and Stevenson, T. C. (2011). "Direct incentive approaches for leatherback turtle conservation," in Conservation of Pacific Sea Turtles, eds P. H. Dutton, D. Squires, and M. Ahmed (Honolulu: University of Hawaii Press), 164-182. doi: 10.1515/9780824860196-013

Gneezy, U., Meier, S., and Rey-Biel, P. (2011). When and why incentives (don't) work to modify behavior. J. Econ. Perspect. 25, 191-210. doi: 10.1257/jep.25. 4.191

Goulder, L. H., and Parry, I. W. H. (2008). Instrument choice in environmental policy. Rev. Env. Econ. Policy 2, 152-174. doi: 10.1093/reep/ren005

Griffiths, V. F., Bull, J. W., Baker, J., and Milner-Gulland, E. J. (2019a). No net loss for people and biodiversity. Conserv. Biol. 33, 76-87. doi: 10.1111/cobi.13184

Griffiths, V. F., Sheremet, O., Hanley, N., Baker, J., Bull, J. W., and Milner-Gulland, E. J. (2019b). Local people's preferences for biodiversity offsets to achieve 'no net loss' for economic developments. Biol. Conserv. 236, 162-170. doi: 10.1016/ j.biocon.2019.05.049

Guillotreau, P., Salladarré, F., Dewals, P., and Dagorn, L. (2011). Fishing tuna around Fish Aggregating Devices (FADs) vs free swimming schools: skipper decisions and other determining factors. Fish. Res. 109, 234-242. doi: 10.1016/ j.fishres.2011.02.007

Hair, C., Foale, S., Daniels, N., Minimulu, P., Aini, J., and Southgate, P. C. (2020). Social and economic challenges to community-based sea cucumber mariculture development in New Ireland province, Papua New Guinea. Mar. Pol. 117:103940. doi: 10.1016/j.marpol.2020.103940

Hall, M., Gillman, E., Minami, H., Mituhasi, T., and Carruthers, E. (2017). Mitigating bycatch in tuna fisheries. Rev. Fish Biol. Fish. 27, 881-908. doi: 10.1007/s11160-017-9478-x

Hall, M., and Roman, M. (2013). Bycatch and Non-Tuna Catch in the Tropical Tuna Purse Seine Fisheries of the World. FAO fisheries and aquaculture technical paper 568., Rome: FAO, 262.

Hall, M. A. (1996). On bycatches. Rev. Fish Biol. Fish. 6, 319-352. doi: 10.1007/ bf00122585

Hall, M. A., Alverson, D. L., and Metuzals, K. I. (2000). By-catch: problems and solutions. Mar. Poll. Bull. 41, 204-219. doi: 10.1016/s0025-326x(00)00111-9

Hamilton, R. J., Hughes, A., Brown, C. J., Leve, T., and Kama, W. (2019). Community-based management fails to halt declines of bumphead parrotfish and humphead wrasse in Roviana Lagoon, Solomon Islands. Coral Reefs 38, 455-465. doi: 10.1007/s00338-019-01801-z

Hannesson, R. (2010). "Individual quotas for bycatches: lessons for the tunadolphin issue," in Conservation and Management of Transnational Tuna 
Fisheries, eds R. Allen, J. Joseph, and D. Squies (Hoboken, NJ: Blackwell-Wiley), 215-224.

Harry, A. V., Tobin, A. J., Simpfendorfer, C. A., Welch, D. J., Mapleston, A., et al. (2011). Evaluating catch and mitigating risk in a multispecies, tropical, inshore shark fishery within the great barrier reef world heritage area. Mar. Freshwater Res. 62, 710-721. doi: 10.1071/mf10155

Helfand, G. (2013). "Standards," in Encyclopedia of Energy, Natural Resources, and Environmental Economics, Vol. 3, ed. J. F. Shogren (Amsterdam: Elsevier), $217-221$.

Helvey, M., Pomeroy, C., Pradhan, N. C., Squires, D., and Stohs, S. (2017). Can the United States have its fish and eat it too? Mar. Policy 75, 62-67. doi: 10.1016/j.marpol.2016.10.013

Hobday, A. J., Maxwell, S. M., Forgie, J., and McDonald, J. (2013). Dynamic ocean management: integrating scientific and technological capacity with law, policy, and management. Stanford Envtl. Law J. 33, 125-165.

Holland, D. S., and Jannot, J. E. (2012). Bycatch risk pools for US west coast groundfish fishery. Ecol. Econ. 78, 132-147. doi: 10.1016/j.ecolecon.2012. 04.010

Holland, D. S., and Martin, C. (2019). Bycatch quotas, risk pools, and cooperation in the Pacific whiting fishery. Front. Mar. Sci. 6:600. doi: 10.3389/fmars.2019. 00600

Holland, D. S., and Schnier, K. (2006). Individual habitat quotas for fisheries. J. Environ. Econ. Manag. 51, 72-92. doi: 10.1016/j.jeem.2005.04.005

Howell, E. A., Kobayashi, D. R., Parker, D. M., Balazs, G. H., and Polovina, J. J. (2008). Turtle Watch: a tool to aid in the bycatch reduction of loggerhead turtles caretta caretta in the Hawaii-based pelagic longline fishery. Endang. Spec. Res. 5, 267-278. doi: 10.3354/esr00096

Innes, J., Pascoe, S., Wilcox, C., Jennings, S., and Paredes, S. (2015). Mitigating undesirable impacts in the marine environment: a review of market-based measures. Front. Mar. Sci. 2:76. doi: 10.3389/fmars.2015.00076

Jaffee, A., Newell, R., and Stavins, R. (2005). A tale of two market failures: technology and environmental policy. Ecol. Econ. 54, 164-174. doi: 10.1016/ j.ecolecon.2004.12.027

Janisse, C., Squires, D., Seminoff, J., and Dutton, P. H. (2010). "Conservation investments and mitigation: the california drift gillnet fishery and pacific Sea turtles," in Handbook of Marine Fisheries Conservation and Management, eds R. Q. Grafton, R. Hilborn, D. Squires, N. Tait, and M. Williams (Oxford: Oxford University Press), 231-240.

Jensen, F., Frost, H., and Abildtrup, J. (2017). Fisheries regulation: a survey of the literature on uncertainty, compliance behavior and asymmetric information. Mar. Policy 81, 167-178. doi: 10.1016/j.marpol.2017.03.028

Johannes, R. E. (1978). Traditional marine conservation in oceania and their demise. Annu. Rev. Ecol. Syst. 9, 349-364. doi: 10.1146/annurev.es.09.110178. 002025

Jones, C. I., and Romer, P. M. (2010). The new Kaldor Facts: ideas, institutions, population, and human capital. Am. Econ. J. Macroecon. 2, 224-245. doi: $10.1257 / \mathrm{mac} .2 .1 .224$

Joyner, C., and Tyler, Z. (2000). Marine conservation versus international free trade: reconciling dolphins with tuna and sea turtles with shrimp. Ocean Dev. Int. Law 31, 127-150. doi: 10.1080/009083200276094

Kahn, P. H., and Friedman, B. (1995). Environmental views and values of children in an inner-city black community. Child Dev. 66, 1403-1417. doi: 10.2307/ 1131654

Kaplan, D. M., Chassot, E., Amandé, J. M., Dueri, S., Demarcq, H., Dagorn, L., et al. (2014). Spatial management of Indian Ocean tropical tuna fisheries: potential and perspectives. ICES J. Mar. Sci. 71, 1728-1749. doi: 10.1093/icesjms/fst233

Katz, M., and Shapiro, C. (1986). Technology adoption in the presence of network externalities. J. Polit. Econ. 94, 822-841. doi: 10.1086/261409

Keith, D. M., Sameoto, J. A., Keyser, F. M., and Ward-Paige, C. A. (2020). Evaluating socio-economic and conservaton impacts of management: a case study of time-area closures on Georges Bank. PLoS One 15:e240322. doi: 10.1371/journal.pone. 0240322

Kerstetter, D. W., and Graves, J. E. (2006). Effects of circle versus J-style hooks on target and non-target species in a pelagic longline fishery. Fish. Res. 80, 239-250. doi: 10.1016/j.fishres.2006.03.032

Kotchen, M. J. (1999). Voluntary provision of public goods for bads: a theory of environmental offsets. Econ. J. 119, 883-899. doi: 10.1111/j.1468-0297.2008. 02215.x
Kotchen, M. J. (2013). Voluntary and information-based approaches to environmental management: a public economics perspective. Rev. Environ. Econ. Policy 7, 276-295. doi: 10.1093/reep/ret012

Kotchen, M. J., and Segerson, K. (2019). On the use of group performance and rights for environmental protection and resource management. Proc. Nat. Acad. Sci. U.S.A. 116, 5285-5292. doi: 10.1073/pnas. 1802881115

Lent, R., and Squires, D. (2017). Reducing marine mammal bycatch in global fisheries: an economics approach. Deep Sea Res. II 140, 268-277. doi: 10.1016/ j.dsr2.2017.03.005

Libecap, G. D. (2014). Addressing global environmental externalities: transaction cost considerations. J. Econ. Lit. 52, 424-479. doi: 10.1257/jel.52.2.424

Little, A. S., Needle, C. L., Hilborn, R., Holland, D. S., and Marshall, C. T. (2015). Real-time spatial management approaches to reduce bycatch and discards: experiences from Europe and the United States. Fish Fish. 16, 576-602. doi: $10.1111 /$ faf. 12080

Little, I. M. D., and Mirrlees, J. A. (1974). Project Appraisal and Planning for Developing Countries. New York, NY: Basic Books.

Lodge, M., Segerson, K., and Squires, D. (2019). "Environmental policy for deep seabed mining," in Environmental Issues of Deep Sea Mining, ed. R. Sharma (Cham: Springer), doi: 10.1007/978-3-030-12696-4_13

Marcovaldi, M. A. (2011). "Project TAMAR-ICMBio," in Conservation of Pacific Sea Turtles, eds P. H. Dutton, D. Squires, and M. Ahmed (Honolulu: University of Hawaii Press), 148-164. doi: 10.1515/9780824860196-012

Maxwell, S. M., Hazen, E. L., Lewison, R. L., Dunn, D. C., Bailey, H., Bograd, S. J., et al. (2015). Dynamic ocean management: defining and conceptualizing realtime management of the ocean. Mar. Policy 58, 42-50. doi: 10.1016/j.marpol. 2015.03.014

Melli, V., Hermann, B., Karlsen, J. D., Feekings, J. P., and Krag, L. A. (2020). Predicting optimal combinations of by-catch reduction devices in trawl gears: a meta-analytical approach. Fish Fish. 21, 252-268. doi: 10.1111/faf. 12428

Melvin, E. F., Guy, T. J., and Read, L. B. (2014). Best practice bycatch mitigation for pelagic longline fisheries targeting tuna and related fisheries. Fish. Res. 149, 5-18. doi: $10.1016 /$ j.fishres.2013.07.012

Miller, S. J., and Deacon, R. T. (2017). Protecting marine ecosystems: regulation versus market incentives. Mar. Resour. Econ. 32, 83-107. doi: 10.1086/689214

Milner-Gulland, E. J., Garcia, S., Arlidge, W., Bull, J., Charles, T., Dagorn, L., et al. (2018). Translating the terrestrial mitigation hierarchy to marine megafauna bycatch. Fish. Fish. 19, 547-561. doi: 10.1111/faf.12273

Misund, O. A., and Beltestad, A. K. (2000). Survival of mackerel and saithe that escape through sorting grids in purse seines. Fish. Res. 48, 31-41. doi: 10.1016/ s0165-7836(00)00118-1

Mize, J. (2014). Report to the North Pacific Fishery Management Council on the 2013 Bering Sea Pollock Mothership Salmon Savings Incentive Plan. ITEM C7 Mothership Salmon Savings Incentive Plan, April 2014. Alaska, AK: North Pacific Fishery Management Council.

Mobius, M., and Rosenblat, T. (2014). Social learning in economics. Ann. Rev. Resour. Econ. 6, 827-847.

Moreno, G., Restrepo, V., Dagorn, L., Hall, M., Murua, J., et al. (2016). Workshop on the Use of Biodegradable Fish Agrregating Devices (FAD). ISSF Technical Report 2016-18A, Washington: International Seafood Sustainability Foundation.

Mukherjee, Z. (2015). An economic approach to understanding the international transfer of bycatch from unilateral bycatch reduction policies. Mar. Policy 51, 190-195. doi: 10.1016/j.marpol.2014.07.024

Murray, K. T., Read, A. J., and Solow, A. R. (2000). The use of time/area closures to reduce bycatch of harbour porpoises: lessons from the gulf of maine sink gillnet fishery. J. Cetacean Res. Manage. 2, 135-141.

Niesten, E., and Gjertsen, H. (2010). Economic Incentives for Marine Conservation. Arlington, TX: Conservation International.

Nyborg, K., Anderies, J. M., Dannenberg, A., Lindahl, T., Schill, C., Schlüter, M., et al. (2016). Social norms as solutions. Science 354, 42-43.

OECD (2006). Optimum Yield (in Fish Harvest). Available online at: https://stats. oecd.org/glossary/detail.asp?ID=1915 (accessed March 8, 2021).

Oremus, M., Leqata, J., and Baker, C. S. (2015). Resumption of traditional drive hunting in the Solomon Islands in 2013. R. Soc. Open Sci. 2:140524. doi: 10.1098/rsos.140524

Ostrom, E. (1990). Governing the Commons: The Evolution of Institutions for Collective Action. Cambridge: Cambridge University Press. 
Pakiding, F., Zohar, K., Allo, A. Y. T., Keroman, S., Lontoh, D., Dutton, P. H., et al. (2020). Community engagement: an integral component of a multifaceted conservation approach for the transboundary western Pacific leatherback. Front. Mar. Sci. 7:549570. doi: 10.3389/fmars.2020.549570

Papworth, S. K., Rist, J., Coad, L., and Milner-Gulland, E. J. (2009). Evidence for shifting baseline syndrome in conservation. Conserv. Lett. 2, 93-100.

Pascoe, S., Innes, J., Holland, D., Finas, M., Thebaud, O., Townsend, R., et al. (2010). Use of incentive-based management systems to limit bycatch and discarding. Int. Rev. Enviro. Resour. Econ. 4, 123-161. doi: 10.1561/101. 00000032

Pascoe, S., Wilcox, C., and Donlan, C. J. (2011). Biodiversity offsets: a costeffective interim solution to seabird bycatch in fisheries? PLoS One 6:e25762. doi: 10.1371/journal.pone.0025762

Pauly, D. (1995). Anecdotes and the shifting baseline syndrome of fisheries. Trends Ecol. Evol. 10:430. doi: 10.1016/s0169-5347(00)89171-5

Price, B., and Van Salisbury, C. (2007). Low-Profile Gillnet Testing in the Deep Water Region of Pamlico Sound, N.C. Morehead City, NC: North Caroline Department of Marine Fisheries.

Prno, J., and Slocombe, S. L. (2012). Exploring the origins of 'social license to operate' in the mining sector: perspectives from governance and sustainability theories. Res. Policy 37, 346-357. doi: 10.1016/j.resourpol.2012.04.002

Quigley, J., and Harper, D. (2006). Compliance with Canada's Fisheries Act: a field audit of habitat compensation projects. Environ. Manag. 37, 336-350. doi: 10.1007/s00267-004-0262-z

Rausser, G. S., Hamilton, M., Kovach, R., and Stifter. (2009). Unintended consequences: the spillover effects of common property regulations. Mar. Policy 33, 24-39. doi: 10.1016/j.marpol.2008.03.020

Reinhardt, J. F., Weaver, J., Latham, P. J., Dell'Apa, A., Serafy, J. E., Browder, J. A., et al. (2017). Catch rate and at-vessel mortality of circle hooks versus J-hooks in pelagic longline fisheries: a global meta-analysis. Fish Fish. 19, 413-430. doi: $10.1111 /$ faf.12260

Restrepo, V. V., Dagorn, L., Itano, D., Justel-Rubio, A., Forget, F., and Moreno, G. (2017). A Summary of Bycatch Issues and ISSF Mitigation Initiatives toDate in Purse Seine Fisheries, with Emphasis on FADs. Available online at: https://www.seafish.org/media/ISSF-2017-06-ASummary-of-Bycatch-Issuesand-ISSF-Mitigation-Activities- to-Date-in-Purse-Seine-Fisheries-withEmphasis-on-FADs.pdf (accessed March 8, 2021).

Rode, J., Gómez-Baggethun, E., and Krause, T. (2015). Motivation crowding by economic incentives in conservation policy: a review of the empirical evidence. Ecol. Econ. 117, 270-282. doi: 10.1016/j.ecolecon.2014.11.019

Rodríguez-Sickert, C., Guzmaìn, R. A., and Cardenas, J. C. (2008). Institutions influence preferences: evidence from a common pool resource experiment. J. Econ. Behav. Organ. 67, 215-227. doi: 10.1016/j.jebo.2007.06.004

Romans, J. T. (1966). Moral suasion as an instrument of economic policy. Am. Econ. Rev. 56, 1220-1226.

Romer, P. M. (1986). Increasing returns and long-run growth. J. Polit. Econ. 94, 1002-1037. doi: 10.1086/261420

Romer, P. M. (1990). Endogenous technological change. J. Polit. Econ. 98, 71-102.

Sarmiento, C. (2006). Transfer function estimation of trade leakages generated by court rulings in the Hawai'i longline fisher. Appl. Econ. 38, 183-190. doi: $10.1080 / 00036840500368078$

Scottish Government (2011). Scottish Government Conservation Credits Scheme: Scheme Rules. Versions 2.1 (11 May 2011).

Segerson, K. (2010). "Can voluntary programs reduce sea turtle bycatch? Insights from the literature in environmental economics," in Handbook of Marine Fisheries Conservation and Management, eds R. Q. Grafton, R. Hilborn, D. Squires, M. Tait, and M. Williams (Oxford: Oxford University Press), 618-629.

Segerson, K. (2011). "Policies to reduce stochastic sea turtle bycatch," in Conservation of Pacific Sea Turtles, eds P. H. Dutton, D. Squires, and M. Ahmed (Honolulu: University of Hawaii Press), 370-395. doi: 10.1515/9780824860 196-021

Segerson, K. (2013). Voluntary approaches to environmental protection and management. Annu. Rev. Resour. Econ. 5, 161-180.

Shiode, D., Hu, F., Shiga, M., Yokota, K., and Tokai, T. (2005). Midwater float system for standardizing hook depths on tuna longlines to reduce sea turtle by-catch. Fish. Sci. 71, 1182-1184. doi: 10.1111/j.1444-2906.2005.01 080.x
Singh, R., and Weninger, Q. (2014). Cap-and-trade bycatch management with costly avoidance and stock uncertainty. Mar. Res. Econ. 30, 97-119. doi: 10. $1086 / 679461$

Sorenson, O. (2018). Innovation policy in a networked world. Innovat. Pol. Econ. 18, 53-77. doi: 10.1086/694407

Squires, D., and Garcia, S. M. (2018). Economic efficiency and the biodiversity mitigation hierarchy with a focus on marine and fishery issues. Conserv. Biol. 32, 989-997. doi: 10.1111/cobi.13155

Squires, D., Restrepo, V., and Garcia, S. M. (2018). Fisheries bycatch reduction within the least-cost biodiversity mitigation hierarchy: conservatory offsets with an application to sea turtles. Mar. Policy 93, 55-61. doi: 10.1016/j.marpol.2018. 03.018

Squires, D., and Vestergaard, N. (2013a). Technical change and the commons. Rev. Econ. Stat. 95, 1769-1787.

Squires, D., and Vestergaard, N. (2013b). Technical change in fisheries. Mar. Policy 42, 286-292. doi: 10.1016/j.marpol.2013.03.019

Squires, D., and Vestergaard, N. (2018). Rethinking the commons problem: technological change, knowledge spillovers, and social learning. J. Environ. Econ. Manage. 91, 1-25. doi: 10.1016/j.jeem.2018.06.011

Thornton, D., Kagan, R. A., and Gunningham, N. (2009). When social norms and pressures are not enough: environmental performance in the trucking industry. Law Soc. Rev. 43, 405-436. doi: 10.1111/j.1540-5893.2009.00377.x

Thorpe, T., and Frierson, D. (2009). Bycatch mitigation assessment for sharks caught in coastal anchored gillnets. Fish. Res. 98, 102-112. doi: 10.1016/j.fishres. 2009.04.003

Torell, E., Crawford, B., Kotowicz, D., Herrera, M. D., and Tobey, J. (2010). Moderating our expectations on livelihoods in ICM: experiences from Thailand, Nicaragua, and Tanzania. Coast. Manag. 38, 216-237. doi: 10.1080/ 08920753.2010.483166

Travers, H., Clements, T., Keane, A., and Milner-Gulland, E. (2011). Incentives for cooperation: the effects of institutional controls on common pool resource extraction in Cambodia. Ecol. Econ. 71, 151-161. doi: 10.1016/j.ecolecon.2011. 08.020

Van Dover, C. L., Aronson, J., Pendleton, L., Smith, S., Arnaud-Haond, S., MorenoMateos, D., et al. (2014). Ecological restoration in the deep sea: desiderata. Mar. Policy 44, 98-106. doi: 10.1016/j.marpol.2013.07.006

Velez, M., Murphy, J., and Stranlund, J. (2010). Centralized and decentralized management of local common pool resources in the developing world: experimental evidence from fishing communities in Colombia. Econ. Inquiry 48, 254-265. doi: 10.1111/j.1465-7295.2008.00125.x

Vestergaard, N. (2010). "Principal-agent problems in fisheries," in Handbook of Fisheries Conservation and Management, eds R. Q. Grafton, R. Hilborn, D. Squires, M. Tait, and M. Williams (Oxford: Oxford University Press), 563-571.

Vicary, S. (2000). Donations to a public good in a large economy. Eur. Econ. Rev. 44, 609-618. doi: 10.1016/s0014-2921(98)00085-3

Wakefield, C. B., Santana-Garcon, J., Dorman, S. R., Blight, S., Denham, A., Wakeford, J., et al. (2016). Performance of bycatch reduction devices varies for chondrichthyan, reptile, and cetacean mitigation in demersal fish trawls: assimilating subsurface interactions and unaccounted mortality. ICES J. Mar. Sci. 74, 343-358. doi: 10.1093/icesjms/fsw143

Walmo, K., Bisack, K., Lew, D. K., and Squires, D. (2016). The economics of protected marine species: concepts in research and management. Front. Mar. Sci. 3:183. doi: 10.3389/fmars.2016.00183

Wang, J., Barkan, J., Fisler, S., Godinez-Reyes, C., and Swimmer, Y. (2013). Developing ultraviolet illumination of gillnets as a method to reduce sea turtle bycatch. Biol. Lett. 9:20130383. doi: 10.1098/rsbl.2013.0383

Ward, P., Lawrence, E., Darbyshire, R., and Hindmarsh, S. (2008). Largescale experiment shows that nylon leaders reduce shark bycatch and benefit pelagic longline fishers. Fish. Res. 90, 100-108. doi: 10.1016/j.fishres.2007.09.034

Watson, J. T., Stram, D. L., and Harmon, J. (2020). Mitigating seafood waste through a bycatch reduction program. Front. Mar. Sci. 7:576431. doi: 10.3389/ fmars.2020.576431

Watson, J. W., Epperly, S. P., Shah, A. K., and Foster, D. G. (2005). Fishing methods to reduce sea turtle mortality associated with pelagic longlines. Can. J. Fish. Aquatic Sci. 62, 965-981. doi: 10.1139/f05-004

Werner, T., Kraus, S., Read, A., and Zollett, E. (2006). Fishing techniques to reduce the bycatch of threatened marine animals. Mar. Technol. Soc. J. 40, 50-68. doi: $10.4031 / 002533206787353204$ 
Western, D., and Wright, R. M. (eds) (1994). Natural Connections. Washington, DC: Island Press.

Wilcox, C., and Donlan, C. J. (2007). Compensatory mitigation as a solution to fisheries by- catch-biodiversity conservation conflicts. Front. Ecol. Environ. $5: 331$.

Wolf, S., Hartl, B., Carroll, C., Neel, M. C., and Greenwald, D. N. (2015). Beyond PVA: why recovery under the endangered species act is more than population viability. Bioscience 65, 200-207. doi: 10.1093/biosci/biu 218

Worldfish Center (2004). "Bellagio blueprint for action on pacific sea turtles," in Conservation of Pacific Sea Turtles, eds P. Dutton, D. Squires, and M. Ahmed (Honolulu: University of Hawaii Press), 15-32. doi: 10.1515/9780824860196004

Wright, J. H., Hill, N. A. O., Roe, D., Rowcliffe, J. M., Kümpel, N. F., Day, M., et al. (2015). Reframing the concept of alternative livelihoods. Cons. Bio. 30, 7-13. doi: $10.1111 /$ cobi.12607
Young, H. P. (1994). Equity: How Groups Divide Goods and Burdens Among Their Members. Princeton: Princeton University Press.

Young, H. P. (2015). The evolution of social norms. Ann. Rev. Econ. 7, 359-387.

Young, H. P. (2008). "Social norms," in New Palgrave Dictionary of Economics, 2nd Edn, eds S. N. Durlauf and L. E. Blume (London: Macmillan).

Conflict of Interest: The authors declare that the research was conducted in the absence of any commercial or financial relationships that could be construed as a potential conflict of interest.

Copyright (c) 2021 Squires, Balance, Dagorn, Dutton and Lent. This is an open-access article distributed under the terms of the Creative Commons Attribution License (CC BY). The use, distribution or reproduction in other forums is permitted, provided the original author(s) and the copyright owner(s) are credited and that the original publication in this journal is cited, in accordance with accepted academic practice. No use, distribution or reproduction is permitted which does not comply with these terms. 